\title{
Drivers and mechanisms for enhanced summer monsoon precipitation over East Asia during the mid-Pliocene in the IPSL-CM5A
}

\author{
Yong Sun ${ }^{1,2} \cdot$ Tianjun Zhou $^{1,2}$ - Gilles Ramstein ${ }^{3}$ - Camille Contoux ${ }^{4}$. \\ Zhongshi Zhang ${ }^{5,6}$
}

Received: 17 November 2014 / Accepted: 11 May 2015 / Published online: 30 May 2015

(c) The Author(s) 2015. This article is published with open access at Springerlink.com

\begin{abstract}
A comparative analysis of East Asian summer monsoon (EASM) precipitation is performed to reveal the drivers and mechanisms controlling the similarities of the mid-Pliocene EASM precipitation changes compared to the corresponding pre-industrial (PI) experiments derived from atmosphere-only (i.e. AGCM) and fully coupled (i.e. CGCM) simulations, as well as the large simulated differences in the mid-Pliocene EASM precipitation between the two simulations. The area-averaged precipitation over the EASM domain is enhanced in the mid-Pliocene compared to the corresponding PI experiments performed by both the AGCM (LMDZ5A) and the CGCM (IPSL-CM5A). Moisture budget analysis reveals that it is the surface warming over East Asia that drives the area-averaged EASM precipitation increase in the mid-Pliocene in both simulations. The surface warming increases the atmospheric moisture content, as revealed by an increase in the thermodynamic
\end{abstract}

Tianjun Zhou

zhoutj@lasg.iap.ac.cn

1 State Key Laboratory of Numerical Modeling for Atmospheric Sciences and Geophysical Fluid Dynamics, Institute of Atmospheric Physics, Chinese Academy of Sciences, Beijing 100029, China

2 Joint Center for Global Change Studies (JCGCS), Beijing 100875, China

3 Laboratoire des Sciences du Climat et de l'Environnement/ IPSL, CEA-CNRS-UVSQ, Gif-sur-Yvette, France

4 Aix-Marseille Université, CNRS, IRD, CEREGE UM34, Aix-en-Provence, France

5 Bjerknes Centre for Climate Research, Uni Research Climate, Allégaten 70, 5007 Bergen, Norway

6 Nansen-Zhu International Research Centre, Institute of Atmospheric Physics, Chinese Academy of Sciences, Beijing 100029, China component of vertical moisture advection, resulting in enhanced mid-Pliocene EASM precipitation compared to PI in both simulations. Moist static energy diagnosis identifies the combined effect of enhanced zonal thermal contrast and column-integrated meridional stationary eddy velocity $\overline{v^{*}}$ and its convergence $\frac{\overline{\partial v^{*}}}{\partial y}$ as the physical mechanisms that sustain the enhancement of mid-Pliocene EASM precipitation in both simulations compared to the PI experiments. This takes place through a strengthening of the EASM circulation and moisture transport into the EASM domain associated with an increase in local moisture convergence in the mid-Pliocene in both simulations. Moisture budget analysis also reveals that the larger area-averaged mid-Pliocene EASM precipitation increase in the CGCM compared to its AGCM component is mainly caused by the dynamical component contributing more to the vertical moisture advection in the CGCM (i.e. IPSL-CM5A) compared to its AGCM (LMDZ5). The large simulated differences in the spatial pattern of the mid-Pliocene EASM precipitation between the two simulations result from the combined effect of enhanced meridional thermal contrast over the EASM domain and increased $\overline{v^{*}}$ convergence over South China in the CGCM simulation compared to the AGCM simulation.

Keywords Mid-Pliocene - EASM precipitation - Thermal contrast - Atmospheric moisture budget - Thermodynamic and dynamic components $\cdot$ Moist static energy diagnosis

\section{Introduction}

The mid-Pliocene warm period $(\sim 3.3-3.0 \mathrm{Ma})$ is widely considered as the most recent warm period in Earth's history when the global average surface air temperature (SAT) 
was higher than the present day (Haywood et al. 2000; Haywood and Valdes 2004). More importantly, this period was the same as or quite similar in many respects to the modern climate, such as the geographic distribution of the continents and oceans, the atmospheric $\mathrm{CO}_{2}$ concentration (estimated to have been slightly higher than the present day at 360-440 ppm), and the sea level (estimated to have been $22 \pm 10 \mathrm{~m}$ higher than the modern level) (Miller et al. 2012). Given the abundance of proxy data and such large similarities with the modern climate, the mid-Pliocene warm period has been recommended as a potential analogue for future climate predictions by the end of the twenty first century (Thompson and Fleming 1996; Jansen et al. 2007; Sun et al. 2013). In particular, Sun et al. (2013) compared the simulated mid-Pliocene climate to that under a Representative Concentration Pathway (RCP) future scenario (RCP4.5) and found that Hadley circulation changes were similar in both simulations, strengthening the idea that the mid-Pliocene could be a useful tool for understanding atmospheric changes in the future.

Given the importance of the mid-Pliocene warm period, data-model comparisons have been performed to better understand the dynamical cause of this warm climate in Earth's history. The PRISM (Pliocene Research, Interpretation and Synoptic Mapping) project was initially devised to reconstruct the sea surface conditions of the mid-Pliocene by utilizing multi-proxy records, the aim being to create the oceanic boundary conditions necessary to drive atmosphere-only models for mid-Pliocene simulation. Recently, the first phase of the Pliocene Modeling Intercomparison Project (PlioMIP1) has been conducted to validate and assess the ability of state-of-the-art climate models to simulate the warm climate of the past (Haywood et al. 2013). Two types of experiments have been conducted, proposed by the PlioMIP guidelines, to investigate the possible causes of the mid-Pliocene warm climate. The first (Experiment 1 ) is performed with atmosphere-only climate models (atmospheric general circulation models; AGCMs) to simulate the mid-Pliocene and pre-industrial (PI) climate. The second (Experiment 2) utilizes fully coupled oceanatmosphere climate models [atmosphere-ocean general circulation models (AOGCMs) or coupled general circulation models (CGCMs)] to perform the mid-Pliocene and PI simulations (Haywood et al. 2010, 2011). All the PlioMIP1 participating models show good performance in reproducing the global SAT warming in the mid-Pliocene (Chan et al. 2011; Bragg et al. 2012; Contoux et al. 2012; Kamae and Ueda 2012; Koenig et al. 2012; Stepanek and Lohmann 2012; Yan et al. 2012a, b; Chandler et al. 2013; Zhang et al. 2012; Zhang and Yan 2012; Rosenbloom et al. 2013; Zheng et al. 2013), despite the mechanisms underpinning the trend remaining controversial (Haywood and Valdes 2004; Hill et al. 2014).
East Asian climate during the mid-Pliocene warm period has also been investigated (Yan et al. 2012a, b), revealing a stronger than present East Asian summer monsoon (EASM) using the Community Atmosphere Model version 3.1 (CAM3.1). This result was subsequently confirmed by multi-model comparison analysis, in both atmosphere-only and coupled model experiments from the PlioMIP (Zhang et al. 2013). However, compared to the EASM, the comparison showed that there is greater uncertainty regarding the East Asian winter monsoon (EAWM) in the mid-Pliocene. Despite the features of the EASM and EAWM during the mid-Pliocene warm period having been revealed well by this multi-model comparison study (Zhang et al. 2013, 2015), a comprehensive comparison of mid-Pliocene EASM precipitation simulated by AGCMs and CGCMs has never been addressed. Changes in EASM precipitation associated with EASM circulation variations have direct and wide societal and economic impacts over East Asia, and thus it is important to investigate the possible factors determining the position of the rain belt and its intensity over East Asia. Sampe and Xie (2010) argued that temperature advection from the southeastern flank of the Tibetan Plateau at $500 \mathrm{hPa}$ is important because of its role in inducing vertical motion and because of its control over the position of the rain belt over East Asia. Moist static energy (MSE) has been proposed to gauge the prominent feature of present day EASM precipitation (Chen and Bordoni 2014a). However, no study has investigated the mechanisms controlling the position of the EASM precipitation during the mid-Pliocene. This is an important topic because it can help provide an insight into the possible status of EASM precipitation in the future, which of course has important social implications.

In this study, an analysis of the similarities and differences of the mid-Pliocene EASM precipitation simulated by an atmosphere-only and a coupled model is carried out. Diagnosis of the moisture budget equation is used to explain the cause of the mid-Pliocene EASM precipitation changes compared to PI in both simulations, as well as the differences between the mid-Pliocene EASM precipitation simulated by the two models.

The paper is organized as follows: The models and experimental design are described in Sect. 2. In Sect. 3, a comparison of the mid-Pliocene EASM precipitation is made using the moisture budget equation. In Sect. 4, we investigate the factors determining the horizontal distribution of the EASM precipitation and then explain the mechanism involved in the simulated mid-Pliocene EASM precipitation changes relative to the PI experiment. The differences between the mid-Pliocene EASM precipitation simulated by the CGCM and AGCM are discussed in Sect. 5. In Sect. 6, the drivers and mechanisms for enhanced mid-Pliocene EASM precipitation, as 
revealed by IPSL-CM5A-LR and its atmospheric component (LMDZ5), are further confirmed by performing multimodel comparisons. Section 7 provides further discussion and a summary.

\section{Experimental design and analysis method}

\subsection{Climate model description}

The climate model used in the present study is IPSLCM5A-LR, which is a state-of-the art coupled GCM developed by Institute Pierre Simon Laplace (Dufresne et al. 2013). This model has been widely used for paleoclimate simulations and future projections. IPSL-CM5A-LR is a coupled climate model including four components: the LMDZ5A atmospheric model, which has a horizontal resolution of $1.875^{\circ}$ latitude $\times 3.75^{\circ}$ longitude and 39 vertical levels $($ R96 $\times$ 95L39) (Hourdin et al. 2013); the NEMOv3.2 ocean model, which has a mean grid spacing about $2^{\circ}$ (latitudinal resolution of $0.5^{\circ}$ near the equator and $1^{\circ}$ in the Mediterranean Sea) and 31 vertical levels in the ocean (10 levels in the top $100 \mathrm{~m})(\mathrm{R} 182 \times 149 \mathrm{~L} 31)$ (Madec 2008); the LIM2 sea-ice model (Louvain-la-Neuve Sea Ice Model) (Fichefet and Morales-Maqueda 1997); and the ORCHIDEE (Organizing Carbon and Hydrology In Dynamic Ecosystems) land surface model (Krinner et al. 2005). IPSL-CM5A-LR couples the ocean, atmosphere, land and sea ice through the OASIS3 coupler (Valcke 2006). For the atmosphere-only simulations, LMDZ5A is used together with the ORCHIDEE land surface model, with fixed vegetation (see Contoux et al. 2012).

\subsection{Experimental designs for the mid-Pliocene and PI simulations}

Following PlioMIP guidelines, two types of simulations for mid-Pliocene warm period are conducted using the atmosphere-only climate model (LMDZ5A) and the fully coupled climate model (IPSL-CM5A-LR). The boundary conditions derived from PRISM3D are set for the midPliocene simulation, as proposed by PlioMIP experimental designs (Contoux et al. 2012). The modern coastline is employed in these simulations to avoid changing the land-sea mask in the ocean model. Differences between the mid-Pliocene and modern topographies are added as anomalies to the IPSL-CM5A-LR model topography (Edwards et al. 1992; Sohl et al. 2009), but include few changes apart from the ice sheets. Imposed ice-sheet and vegetation reconstructions are derived from PRISM3D (Hill et al. 2007; Salzmann et al. 2008), and include a Greenland Ice Sheet reduced by $50 \%$ in volume, and an Antarctic Ice Sheet reduced by $33 \%$. Prescribed vegetation includes a reduction of most present-day desert, and a northward shift of temperate forest biomes. The AGCM simulation for the mid-Pliocene is forced by prescribed monthly SST derived from the PRISM reconstruction. The orbital configuration, solar constant, greenhouse gases and aerosols are specified as similar to in the PI experiment except that the atmospheric $\mathrm{CO}_{2}$ concentration is prescribed at $405 \mathrm{ppm}$. More details on the experimental design, the implementation of PlioMIP boundary conditions, as well as the general features of the mid-Pliocene climate simulated by LMDZ5A and IPSL-CM5A can be found in Contoux et al. (2012).

The PI experiments are performed by both the AGCM and the CGCM to enable direct comparisons with the corresponding mid-Pliocene simulations. Greenhouse gas concentrations, the solar constant and orbital parameters are set to the PI values recommended by the Coupled Model Intercomparison Project Phase 3 and Phase 5 (CMIP3 and CMIP5). The solar constant is $1365 \mathrm{~W} \mathrm{~m}^{-2}$. The $\mathrm{CO}_{2}$ and $\mathrm{CH}_{4}$ concentrations are fixed at $280 \mathrm{ppm}$ and $760 \mathrm{ppb}$, respectively.

The IPSL-CM5A-LR model and its atmospheric component (LMDZ5A) performance as well as other PlioMIP models in estimating the global annual mean SAT for the mid-Pliocene, i.e. at around $2{ }^{\circ} \mathrm{C}$ higher than present (Contoux et al. 2012; Haywood et al. 2013). Here, we focus mainly on the similarities and differences between the EASM precipitation changes in the context of the midPliocene warm period simulated by IPSL-CM5A-LR and LMDZ5A.

\subsection{Methods}

\subsubsection{Moisture budget analysis}

Moisture budget analysis is widely used to understand the global and regional precipitation changes (Yoon and Chen 2005; Chou and Lan 2012; Hsu et al. 2012). Here, to estimate the processes that are important for the EASM precipitation, the moisture budget equation is analyzed (Seo et al. 2013). The vertically integrated moisture budget equation can be expressed as

$\langle\nabla \cdot q \vec{V}\rangle=E-P+\operatorname{Res}$

where $q$ is specific humidity, $\vec{V}$ is three-dimensional wind, and \langle\rangle represents a vertical integration from 1000 to $100 \mathrm{hPa}$. $E$ is surface evaporation and $P$ is precipitation. Res is the residual term, including transient eddies and nonlinear effects, and is relatively small compared with other terms.

The term on the left-hand side in Eq. (1), moisture flux convergence $(\langle\nabla \cdot q \vec{V}\rangle)$, is further divided into three terms: vertical moisture advection $-\left\langle\omega \partial_{P} q\right\rangle(\omega$ is vertical velocity 
in the pressure coordinate); horizontal moisture advection $-\left\langle\vec{V}_{H} \cdot \nabla q\right\rangle\left(\vec{V}_{\mathrm{H}}\right.$ is horizontal wind); and moisture divergence $-\left\langle q \cdot \nabla \cdot \vec{V}_{H}\right\rangle$. Thus, Eq. (1) can be expressed as

$P=E-\left\langle\omega \partial_{P} q\right\rangle-\left\langle\vec{V}_{H} \cdot \nabla q\right\rangle-\left\langle q \cdot \nabla \cdot \vec{V}_{H}\right\rangle+$ Res.

Changes of vertical moisture advection can be further divided into thermodynamic and dynamic components, to assess the relative contribution of specific humidity and atmospheric circulation to regional precipitation variability (Chou and Lan 2012). Thus,

$-\left\langle\omega \partial_{p} q\right\rangle^{\prime} \approx-\left\langle\bar{\omega} \partial_{p} q^{\prime}\right\rangle-\left\langle\omega^{\prime} \partial_{p} \bar{q}\right\rangle$,

where ${ }^{-}$is climatology and \langle\rangle$^{\prime}$ is the departure of change from the climatology, and $-\left\langle\bar{\omega} \partial_{p} q^{\prime}\right\rangle$ and $-\left\langle\omega^{\prime} \partial_{p} \bar{q}\right\rangle$ denote the thermodynamic and dynamic contribution to the changes of vertical moisture advection, respectively. The thermodynamic contribution is directly affected by specific humidity changes, which is closely tied to temperature changes roughly following Clausius-Clapeyron (C-C) equation (Chou et al. 2013). The dynamic contribution is directly linked to changes in large-scale vertical motion (Chou et al. 2013).

\subsubsection{Moist static energy diagnosis}

Following Chen and Bordoni (2014a), MSE is selected to quantify the relative roles of temperature, moisture, and radiative processes in sustaining the horizontal distribution of the mid-Pliocene EASM precipitation. The highly simplified MSE balance in the atmospheric column is expressed as

$\left\langle\overline{\omega \partial_{p} M S E}\right\rangle=\overline{F^{n e t}}-\langle\overline{V . \nabla E}\rangle$,

where MSE is the atmospheric moist static energy, $E$ is the atmospheric moist enthalpy, and $\overline{F^{n e t}}$ is the net energy flux into the atmosphere. The atmospheric moist static energy and moist enthalpy are expressed as MSE $=C_{p} T+g z+L_{v} q$ and $E=C_{p} T+L_{v} q$, where $C_{p}$ is specific heat at constant pressure, $T$ is temperature, $z$ is geopotential height, $g$ is gravitational acceleration, $L_{v}$ is latent heat of vaporization, and $q$ is specific humidity. The MSE stratification in the atmosphere is negative, hence regions of positive (negative) vertical MSE advection correspond to ascending (descending) vertical motion. The time-mean advection of the atmospheric energy $\langle\overline{V \cdot \nabla E}\rangle$ can be written as

$$
\begin{aligned}
\langle\overline{V \cdot \nabla E}\rangle= & \langle[\bar{V}] \cdot[\overline{\nabla E}]\rangle+\left\langle[\bar{V}] \cdot \overline{\nabla E^{*}}\right\rangle+\left\langle\overline{V^{*}} \cdot[\overline{\nabla E}]\right\rangle \\
& +\left\langle\overline{V^{*}} \cdot \overline{\nabla E^{*}}\right\rangle+\left\langle\overline{V^{\prime}} \cdot \overline{\nabla E^{\prime}}\right\rangle,
\end{aligned}
$$

where $(\cdot)^{\prime}$ and $(\cdot)^{*}$ denote deviations from the time mean $(\cdot)$ and zonal mean $[\cdot]$, respectively. The first term on the right-hand side of Eq. (5) is the zonal-mean energy advection by the zonal mean flow; the second term is the advection of the stationary eddy energy by the zonal-mean flow; the third term is the advection of the zonal-mean energy by the stationary eddy velocity; the fourth term is the advection of the stationary eddy energy by the stationary eddy velocity; the fifth term is the advection of the transient eddy energy by the transient eddies. The first term is very small compared with the other terms and can be neglected. A more detailed description of the MSE used to analyze the EASM can be found in Chen and Bordoni (2014a).

\section{EASM precipitation changes in the mid-Pliocene}

\subsection{Simulated spatial distribution of the EASM precipitation changes in the mid-Pliocene}

The EASM precipitation in the mid-Pliocene simulated by the coupled model and the atmosphere-only model share similarities and differences (Fig. 1). Figure 1a, b show the maps of the simulated differences in precipitation between the mid-Pliocene and PI experiments. The red boxes in Fig. 1a, b denote the selected EASM domain for the present study. The EASM precipitation changes in the mid-Pliocene derived from the AGCM simulation are nonuniform, with a decrease in precipitation along the southeastern coast of China and increased precipitation on the northwestern flank (Fig. 1a) compared to PI. In contrast, a general increase in summer monsoon precipitation over East Asia is seen in the coupled simulation for the mid-Pliocene warm period compared to PI, associated with a maximal increase of precipitation confined to southern China (Fig. 1b).

Despite the area-averaged mean summer monsoon precipitation over East Asia increasing in both simulations when compared with the corresponding PI experiments (Fig. 3b), important differences exist between the AGCM and CGCM simulations for the mid-Pliocene. Compared with the AGCM simulation, the increased mid-Pliocene EASM precipitation in the CGCM simulation is confined to the south of $25^{\circ} \mathrm{N}$, while the decreased precipitation anomalies are northward of $25^{\circ} \mathrm{N}$ (Fig. 1c).

What caused the similarities and large differences in the horizontal distributions of EASM precipitation in the mid-Pliocene between the two simulations? There are differences in SAT and SST between the mid-Pliocene and PI (Fig. 2), and between the CGCM and AGCM for the midPliocene (Fig. 2c, d). What is the impact of these differences in SST and SAT on the precipitation patterns of the EASM? What are the dominant mechanisms through which the SST and SAT differences impact upon the EASM 

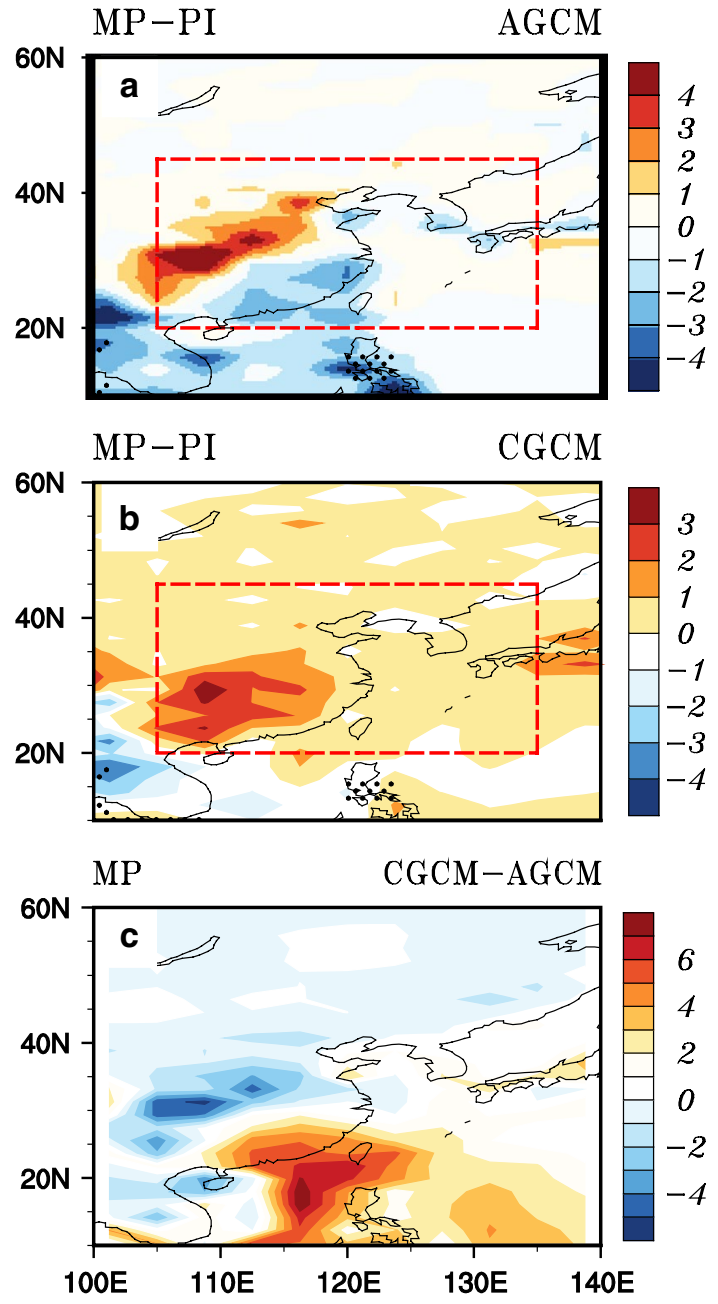

Fig. 1 The horizontal distributions of JJA precipitation (units: $\mathrm{mm} /$ day) differences between the mid-Pliocene (MP) and PI experiments in the a AGCM and $\mathbf{b}$ CGCM. $\mathbf{c}$ The simulated JJA MP precipitation difference between the CGCM and AGCM. The red box denotes the EASM domain $\left(20^{\circ}-45^{\circ} \mathrm{N}, 105^{\circ}-135^{\circ} \mathrm{E}\right)$

precipitation? To answer these questions, we analyze the moisture budget and diagnose the MSE in the following section.

\subsection{Moisture budget analysis of the area-averaged EASM precipitation changes in the mid-Pliocene}

Moisture budget analysis is carried out to examine the simulated area-averaged EASM precipitation in the mid-Pliocene warm period. Climatologically, local surface evaporation and vertical moisture advection rather than horizontal moisture advection are the main contributors to the precipitation over East Asia $\left(20^{\circ}-45^{\circ} \mathrm{N}, 105^{\circ}-135^{\circ} \mathrm{E}\right)$ (Fig. 3a). Furthermore, moisture divergence contributes a smaller amount to sustain the mean state of the EASM precipitation when compared with local surface evaporation and vertical moisture advection, while the contribution of the residual term is negative (Fig. 3a).

Moisture budget analysis additionally reveals the dominant factor determining the simulated similarities of the EASM precipitation changes in the mid-Pliocene between the two simulations. Figure $3 b$ shows the AGCM- and CGCM-simulated moisture budget differences between the mid-Pliocene and PI. The simulated enhancement of mid-Pliocene precipitation over the EASM domain in both simulations is mainly attributed to increased vertical moisture advection $\left(-\left\langle\omega \partial_{p} q\right\rangle^{\prime}\right)$. The vertical moisture advection $\left(-\left\langle\omega \partial_{p} q\right\rangle^{\prime}\right)$ is further divided into thermodynamic and dynamic components to assess the relative contribution of specific humidity $(q)$ and atmospheric circulation $(\omega)$ to the enhanced mid-Pliocene EASM precipitation. The results show that the simulated increase of vertical moisture advection $\left(-\left\langle\omega \partial_{p} q\right\rangle^{\prime}\right)$ over East Asia results from an increase in the thermodynamic component $\left(-\left\langle\bar{\omega} \partial_{p} q^{\prime}\right\rangle\right)$, thereby leading to enhanced EASM precipitation in the mid-Pliocene AGCM and CGCM simulations (Fig. 3b). The simulated increase in the thermodynamic component's contribution to the enhanced EASM precipitation in the mid-Pliocene essentially reflects the increasing moisture in the atmospheric column in response to surface warming. For instance, a $1.2 \mathrm{~K}(1.8 \mathrm{~K})$ increase in summer (June-JulyAugust; JJA) mean SAT over East Asia (Fig. 2) derived from the AGCM (CGCM) simulation for the mid-Pliocene produces about a $6.3 \%(7.8 \%)$ increase in the atmospheric moisture content.

Moisture budget analysis is also used to reveal what causes the large aforementioned differences of the midPliocene EASM precipitation between the AGCM and CGCM simulations. The mean JJA EASM precipitation in the mid-Pliocene is larger in the coupled simulation than in the atmosphere-only simulation (Fig. 3a, c). There is also a larger increase in the mid-Pliocene EASM precipitation relative to the PI experiment in the coupled model (IPSLCM5A-LR) compared to that in its atmospheric component alone (LMDZ5A) (Fig. 3b). The simulated larger increase in the mid-Pliocene EASM precipitation in the coupled model results mainly from the larger vertical moisture advection $\left(-\left\langle\omega \partial_{p} q\right\rangle^{\prime}\right)$, which is due to the larger increase in the dynamic component $\left(-\left\langle\omega^{\prime} \partial_{p} \bar{q}\right\rangle\right)$, itself closely related to the enhanced vertical motion in the coupled simulation compared to the atmosphere-only simulation (Fig. 3c).

Moisture budget analysis provides a useful way to identify the driver of the enhanced summer monsoon precipitation over East Asia during the mid-Pliocene in the atmosphere-only and coupled simulations with IPSL-CM5A. In essence, we are able to explain that it is the increase in SAT over East Asia that drives the increased EASM precipitation in the mid-Pliocene simulations compared to PI: The increase in SAT produces an increase in atmospheric 
Fig. 2 Horizontal distributions of JJA-averaged SAT (units: ${ }^{\circ} \mathrm{C}$ ) differences between the midPliocene and PI experiments derived from the a AGCM and b CGCM. c Simulated mid-Pliocene SAT (units: ${ }^{\circ} \mathrm{C}$ ) differences between the CGCM and AGCM. d SST (units: ${ }^{\circ} \mathrm{C}$ ) bias between the CGCM and PRISM3 SST imposed in the AGCM
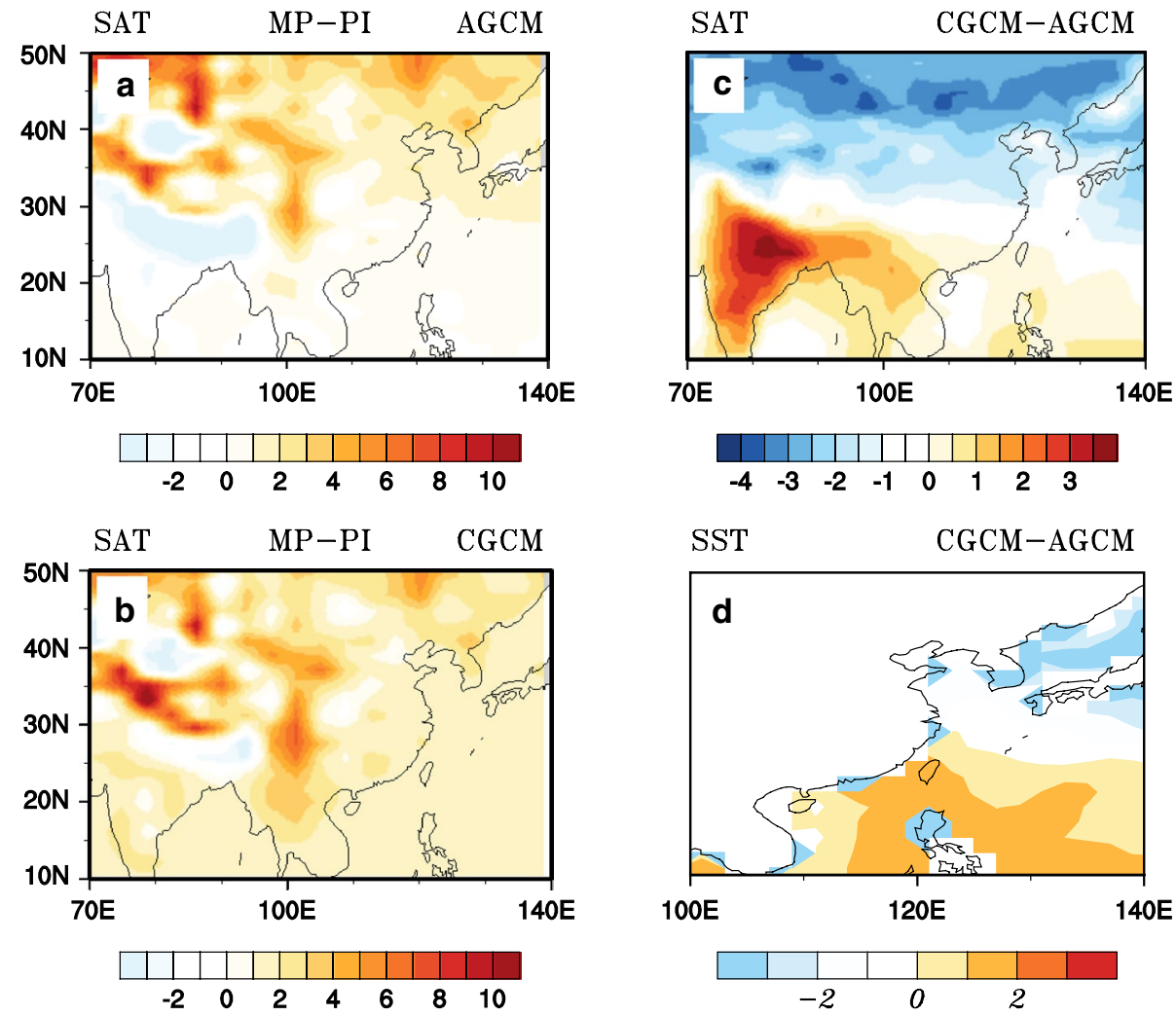

moisture content, revealed by the increase of the thermodynamic component of the vertical moisture advection. Additionally, the dynamic component contributes more to the vertical moisture advection in the coupled simulation than in the atmosphere-only simulation (Fig. 3c). That is why there is a larger increase in the mid-Pliocene precipitation in the coupled model simulation than in the atmosphereonly simulation. This essentially reveals an enhanced role of vertical motion in the mid-Pliocene EASM precipitation increase in the coupled model.

\section{The dominant factors determining the EASM precipitation changes in the mid-Pliocene}

The cause of the enhanced area-averaged EASM precipitation in both the mid-Pliocene simulations compared to the corresponding PI simulations, as well as the simulated differences of the mid-Pliocene EASM precipitation between the two simulations, has been revealed in the previous section by performing a moisture budget analysis in the EASM domain. But what is the mechanism that sustains the spatial distribution of this enhanced mid-Pliocene EASM precipitation in both simulations, and the large differences in the mid-Pliocene EASM precipitation between the two simulations? MSE has recently been proposed as an approach to reveal the physical mechanism underlying the observed maintenance of EASM precipitation (Chen and Bordoni 2014a), and has also been used to assess model performance in simulating EASM precipitation (Chen and Bordoni 2014b).

\subsection{Explaining the EASM precipitation changes in the mid-Pliocene using MSE budget analysis}

Following Chen and Bordoni (2014a), MSE budget analysis is used to reveal the possible factor determining the EASM precipitation changes in the mid-Pliocene derived from the AGCM and CGCM simulations. We first examine the JJA-averaged MSE budget integrated from the surface to $100 \mathrm{hPa}$ derived from the AGCM simulation for the PI and mid-Pliocene climate. The spatial distributions of vertical MSE advection $\left(\left\langle\overline{\omega \partial_{p} M S E}\right\rangle\right)$ derived from the AGCM simulation for the PI and mid-Pliocene experiments resemble the corresponding large-scale summertime precipitation pattern over East Asia (Fig. 4a, d, contours). Given that vertical MSE advection $\left(\left\langle\overline{\omega \partial_{p} M S E}\right\rangle\right)$ is computed as the vertically integrated product of vertical velocity in the $p$-coordinates $\omega$ and $\partial_{p} M S E$, associated with the column-integrated negative $\partial_{p} M S E$ in the troposphere (i.e. $\left\langle\partial_{p} M S E\right\rangle<0$ ), the regions where the vertical MSE advection is positive $\left(\left\langle\overline{\omega \partial_{p} M S E}\right\rangle>0\right)$ thus correspond to the ascending motion over East Asia, and vice versa (Chen and Bordoni 2014a, b). Therefore, the 


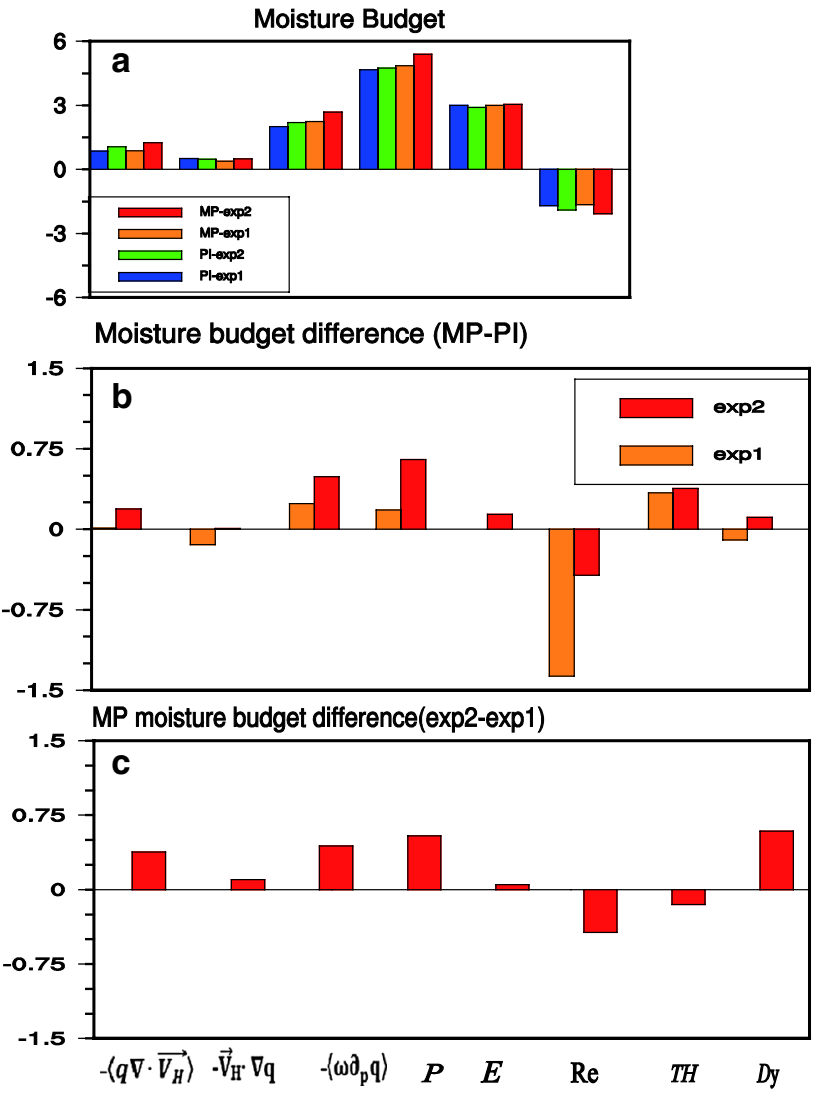

Fig. 3 Simulated moisture budget analysis (units: $\mathrm{mm} \mathrm{day}^{-1}$ ): a JJA mean; $\mathbf{b}$ moisture budget difference between the mid-Pliocene (MP) and PI experiments derived from the AGCM and CGCM. Panel $\mathbf{c}$ is the same as $\mathbf{b}$ except for the simulated MP moisture budget difference between the AGCM and CGCM

vertical MSE advection $\left(\left\langle\overline{\omega \partial_{p} M S E}\right\rangle\right)$ can be considered as a good gauge to identify the vertical motion over East Asia. These results also provide an alternative way to understand the mechanism sustaining the rain belt position over East Asia by revealing the dominant factor determining the horizontal distribution of column-integrated vertical MSE advection $\left(\left\langle\overline{\omega \partial_{p} M S E}\right\rangle\right)$.

As shown in Fig. 4, the vertically integrated JJA-averaged vertical MSE advection $\left(\left\langle\overline{\omega \partial_{p} M S E}\right\rangle\right)$ derived from the PI and mid-Pliocene experiments simulated by the AGCM are further partitioned into two terms: net energy flux into the atmospheric column $\overline{F^{n e t}}$. and vertically integrated horizontal moist enthalpy advection $(-\langle\overline{V \cdot \nabla E}\rangle)$. The spatial distribution of the horizontal moist enthalpy advection $(-\langle\overline{V \cdot \nabla E}\rangle)$ over East Asia derived from the PI and mid-Pliocene experiments is similar to the spatial distribution of the vertical MSE advection $\left(\left\langle\overline{\omega \partial_{p} M S E}\right\rangle\right.$ ). (Figure $4 \mathrm{c}, \mathrm{f}$ ), while the net energy flux into the atmospheric column $\left(\overline{F^{n e t}}\right)$ over East Asia exhibits a horizontal distribution that is distinctly different to that of the vertical MSE advection $\left(\left\langle\overline{\omega \partial_{p} M S E}\right\rangle\right)$, with positive values over the China mainland and minimal net energy flux into the atmospheric column $\left(\overline{F^{n e t}}\right)$ extending from the Bohai Sea to Japan sea (Fig. 4b, e). Thus, the spatial patterns of JJA-averaged vertical MSE advection $\left(\left\langle\overline{\omega \partial_{p} M S E}\right\rangle\right)$ over East Asia derived from the PI and midPliocene experiments simulated by the AGCM are largely determined by moist enthalpy advection $(-\langle\overline{V \cdot \nabla E}\rangle)$ rather than the energy flux in the atmospheric column $\left(\overline{F^{n e t}}\right)$.

We also examine the AGCM-simulated differences of the following three terms between the mid-Pliocene and PI experiments: $\left\langle\overline{\omega \partial_{p} M S E}\right\rangle, \overline{F^{n e t}},-\langle\overline{V \cdot \nabla E}\rangle$. There are large similarities in the AGCM-simulated spatial patterns between the vertical MSE advection $\left(\left\langle\overline{\omega \partial_{p} M S E}\right\rangle\right)$ and EASM precipitation changes in the mid-Pliocene (Fig. 4g), indicating that vertical MSE advection $\left(\left\langle\overline{\omega \partial_{p} M S E}\right\rangle\right)$ is a useful gauge to measure the horizontal distributions of the AGCM-simulated EASM precipitation changes in the midPliocene (Figs. 1a, 4g). The simulated vertical MSE advection $\left(\left\langle\overline{\omega \partial_{p} M S E}\right\rangle\right)$ decreases along the southeastern coast of China, and increased vertical MSE advection $\left(\left\langle\overline{\omega \partial_{p} M S E}\right\rangle\right)$ on the northwestern flank largely results from the horizontal moist enthalpy advection $(-\langle\overline{V \cdot \nabla E}\rangle)$ changes in the mid-Pliocene compared to PI (Fig. 4i). In contrast, changes in the AGCM-simulated net energy flux into the atmospheric column $\left(\overline{F^{n e t}}\right)$ in the mid-Pliocene are much smaller compared to those of horizontal moist enthalpy advection $(-\langle\overline{V \cdot \nabla E}\rangle)$, and thus its contribution to the changes in vertical MSE advection $\left(\left\langle\overline{\omega \partial_{p} M S E}\right\rangle\right)$ can be neglected.

Following the same analysis method, we also examine the MSE budget-related variables of vertical MSE advection $\left(\left\langle\overline{\omega \partial_{p} M S E}\right\rangle\right)$, net energy flux into the atmospheric column $\left(\overline{F^{n e t}}\right)$, and horizontal moist enthalpy advection $(-\langle\overline{V \cdot \nabla E}\rangle)$, as derived from the CGCM simulations. The spatial patterns of JJA-averaged vertical MSE advection $\left(\left\langle\overline{\omega \partial_{p} M S E}\right\rangle\right)$ derived from the CGCM simulations for the PI and mid-Pliocene experiments resemble the horizontal distributions of the corresponding JJA-averaged EASM precipitation derived from the PI and mid-Pliocene experiments, respectively (Fig. 5a, d, contours). This result suggests that vertical MSE advection $\left(\left\langle\overline{\omega \partial_{p} M S E}\right\rangle\right)$ is also a good indicator of the spatial pattern of the CGCM-simulated summer monsoon precipitation over East Asia. The net energy flux into the atmospheric column $\left(\overline{F^{n e t}}\right)$ and horizontal moist enthalpy advection $(-\langle\overline{V \cdot \nabla E}\rangle)$ derived from the CGCM simulation are also shown in order to assess the relative importance of these terms in sustaining the spatial distributions of JJA-averaged vertical MSE advection $\left(\left\langle\overline{\omega \partial_{p} M S E}\right\rangle\right)$ and its changes in the mid-Pliocene (Fig. 5). The CGCM-simulated spatial patterns of vertical MSE advection $\left(\left\langle\overline{\omega \partial_{p} M S E}\right\rangle\right)$ are also largely determined by the horizontal distributions of horizontal moist enthalpy advection $(-\langle\overline{V \cdot \nabla E}\rangle)$ with respect to the mean state of vertical 


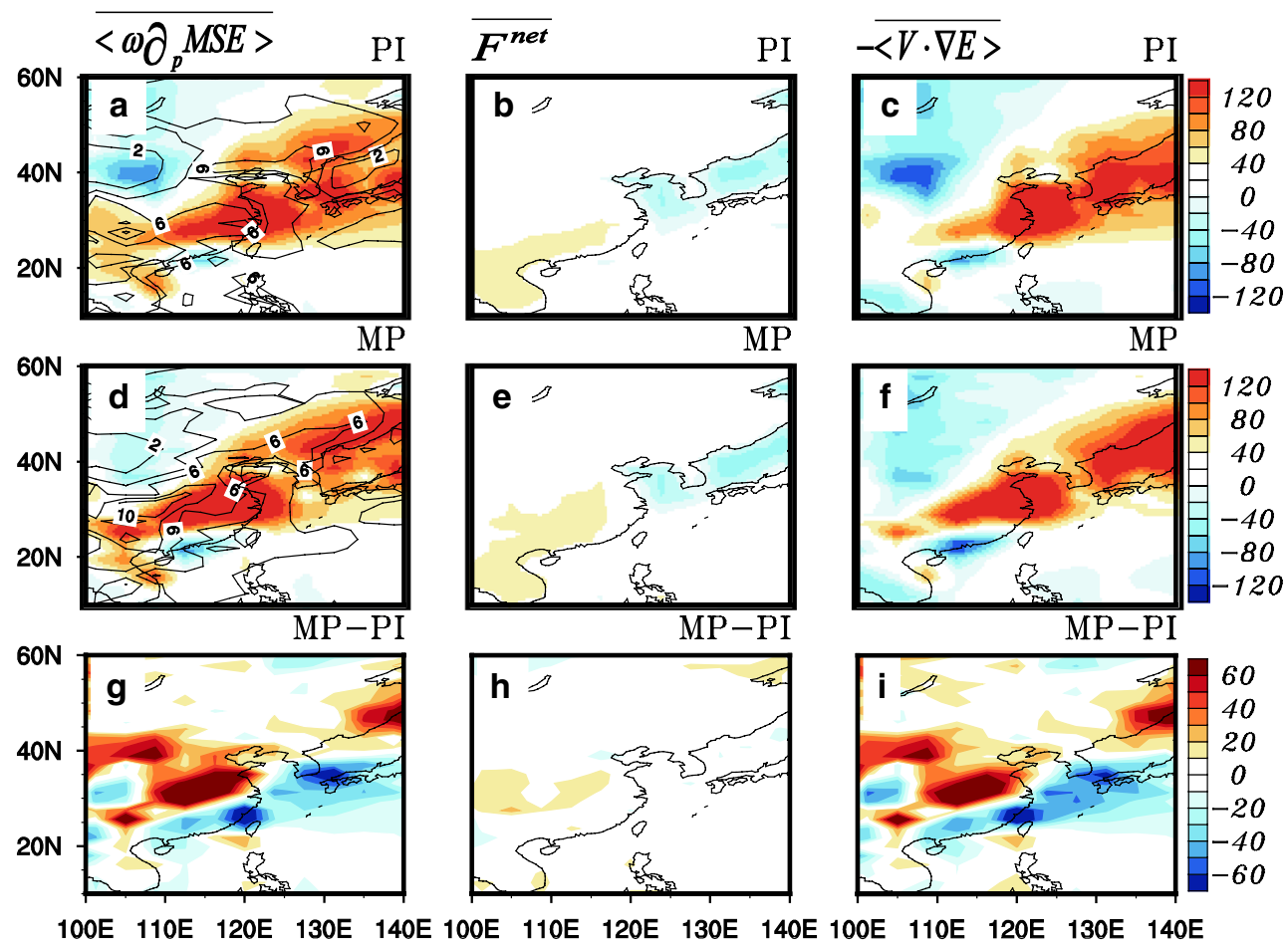

Fig. 4 The vertical MSE advection $\left(\left\langle\overline{\omega \partial_{p} M S E}\right\rangle\right.$ ) (left column, units: $\mathrm{W} \mathrm{m}^{-2}$ ) is partitioned into two terms: net energy flux into the atmospheric column, $\overline{F^{n e t}}$ (middle column, units: $\mathrm{W} \mathrm{m}^{-2}$ ); and vertically integrated horizontal moist enthalpy advection, $-\langle\overline{V \cdot \nabla E}\rangle$ (right column, units: $\mathrm{W} \mathrm{m}^{-2}$ ). The three terms of $\left\langle\overline{\omega \partial_{p} M S E}\right\rangle, \overline{F^{n e t}}$ and $-\langle\overline{V \cdot \nabla E}\rangle$ derived from the PI experiment simulated by the AGCM are shown as a-c, respectively. Panels $\mathbf{d}-\mathbf{f}$ are the same as $\mathbf{a}-\mathbf{c}$ except

MSE advection $\left(\left\langle\overline{\omega \partial_{p} M S E}\right\rangle\right)$ and its changes in the midPliocene (Fig. 5).

In brief, the spatial patterns of the summer monsoon precipitation over East Asia with respect to the mean state and its changes in the mid-Pliocene, as revealed by the coupled model and its atmospheric component alone, are explained well by the spatial patterns of vertical MSE advection $\left(\left\langle\overline{\omega \partial_{p} M S E}\right\rangle\right)$, which are largely determined by the horizontal distributions of moist enthalpy advection $(-\langle\overline{V \cdot \nabla E}\rangle)$ in both simulations. However, the mechanisms controlling the spatial pattern of moist enthalpy advection $(-\langle\overline{V \cdot \nabla E}\rangle)$ remain to be further analyzed, so as to provide a reasonable explanation for the enhanced EASM precipitation in the mid-Pliocene. This is the focus of the following section.

\subsection{Identifying the dominant factors determining the EASM precipitation changes in the mid-Pliocene}

As mentioned above, column-integrated horizontal moist enthalpy advection $(-\langle\overline{V \cdot \nabla E}\rangle)$ is an effective metric to describe the spatial distributions of AGCM- and CGCMsimulated summer monsoon precipitation over East Asia (Figs. 4, 5). According to Eq. (5), this term $(-\langle\overline{V \cdot \nabla E}\rangle)$ for the results from the mid-Pliocene simulated by the AGCM. The simulated differences of the three terms between the mid-Pliocene and PI experiments are shown as $\mathbf{g}-\mathbf{i}$, respectively. $\left\langle\overline{\omega \partial_{p} M S E}\right\rangle$ is defined as the sum of $\overline{F^{n e t}}$ and $-\langle\overline{V \cdot \nabla E}\rangle$, as suggested by Chen and Bordoni (2014a). The contours in a, d represent the JJA-averaged EASM precipitation derived from the AGCM and CGCM, respectively

can be decomposed into five terms. Here, we have only

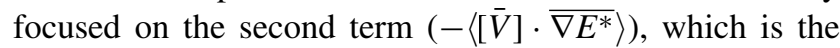
advection of the stationary eddy energy by the zonalmean flow, and the third term $\left(-\left\langle\overline{V^{*}} \cdot[\overline{\nabla E}]\right\rangle\right)$, which is the advection of the zonal-mean energy by the stationary eddy velocity, while the other terms on the right-hand side in Eq. (5) are neglected, as suggested by Chen and Bodorni (2014a, b). Given that atmospheric moist enthalpy $(E)$ can be expressed as a sum of dry enthalpy $C_{p} \mathrm{~T}$ and latent heating $\left(L_{v} q\right)$, each of the aforementioned $E$-relevant advection terms $\left(-\langle\overline{V \cdot \nabla E}\rangle,-\left\langle[\bar{V}] \cdot \overline{\nabla E^{*}}\right\rangle,-\left\langle\overline{V^{*}} \cdot[\overline{\nabla E}]\right\rangle\right)$ can be further represented by the sum of the corresponding temperature-relevant advection (Figs. 6, 7, middle panels) and specific humidity-relevant advection (Figs. 6, 7, right-hand panels).

As shown in Fig. 6a, d and g, the JJA-averaged variables of $-\langle\overline{V \cdot \nabla E}\rangle,-\left\langle[\bar{V}] \cdot \overline{\nabla E^{*}}\right\rangle$ and $-\left\langle\overline{V^{*}} \cdot[\overline{\nabla E}]\right\rangle$ derived from the AGCM simulation for the PI (contours) and mid-Pliocene (shading) experiments, associated with separate contributions from dry enthalpy (Fig. 6b, e, h) and latent heating (Fig. 6c, f, i), are firstly examined to identify the dominant factors determining the JJA-averaged moist enthalpy advection $(-\langle\overline{V \cdot \nabla E}\rangle)$, prior to seeking the 


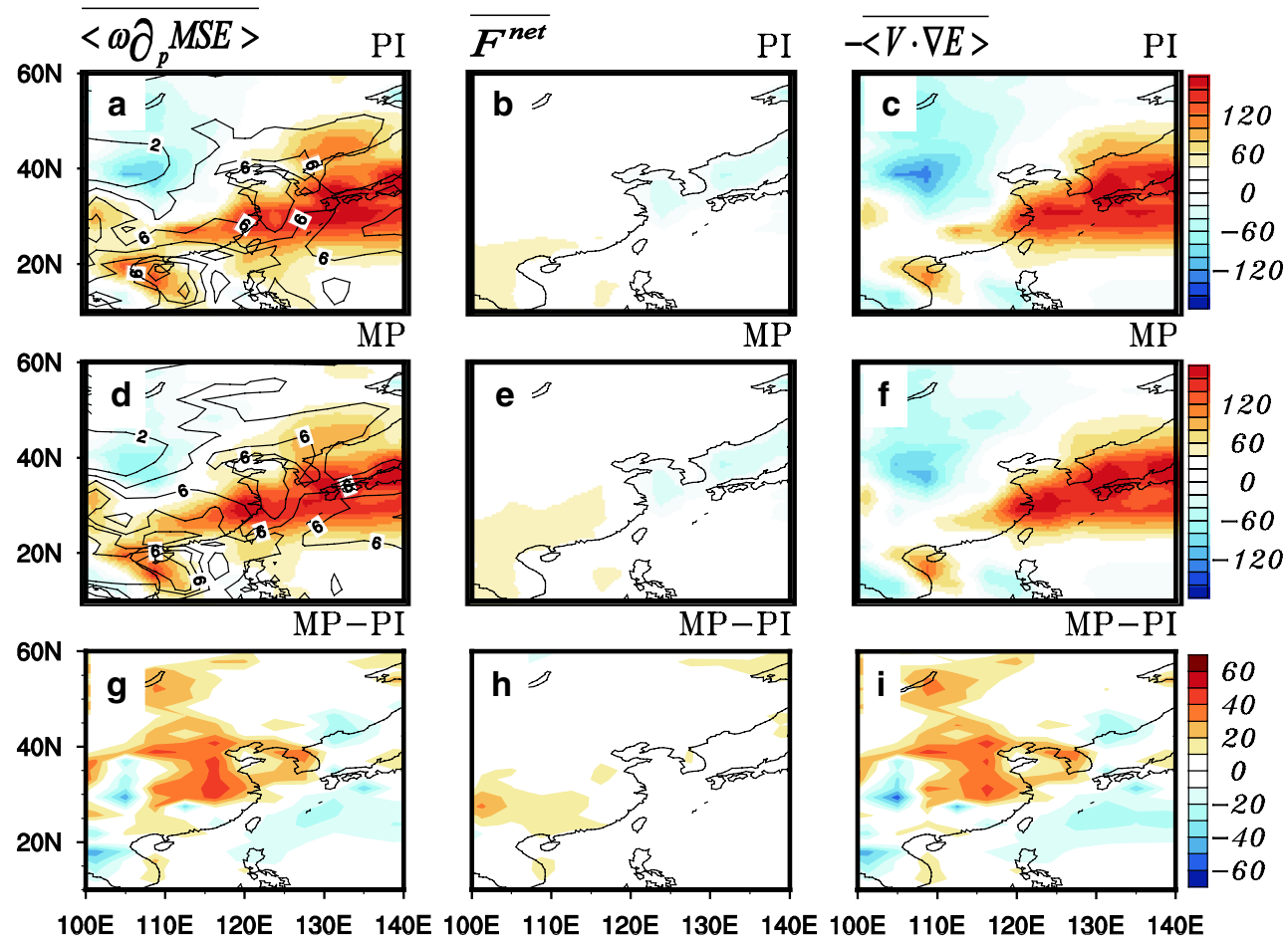

Fig. 5 As in Fig. 4 except for the results from the CGCM simulation (units: $\mathrm{W} \mathrm{m}^{-2}$ )

dominant factors determining the moist enthalpy advection $(-\langle\overline{V \cdot \nabla E}\rangle)$ changes in the mid-Pliocene. The AGCMsimulated moist enthalpy advection $(-\langle\overline{V \cdot \nabla E}\rangle)$ (Fig. 6a) derived from the PI and mid-Pliocene experiments is largely determined by the spatial patterns of the advection of the stationary eddy energy by the zonal-mean flow $\left(-\left\langle[\bar{V}] \cdot \overline{\nabla E^{*}}\right\rangle\right)$ (Fig. 6d) and the advection of the zonalmean energy by the stationary eddy velocity $\left(-\left\langle\overline{V^{*}} \cdot[\overline{\nabla E}]\right\rangle\right)$ (Fig. 6g). The moist enthalpy advections $(-\langle\overline{V \cdot \nabla E}\rangle)$ (Fig. 6a) derived from the PI and mid-Pliocene experiments are both largely determined by the total dry enthalpy advection $(-\langle-C p \overline{V \cdot \nabla T}\rangle$, Fig. 6b), while the AGCMsimulated total latent heating advection $(-\langle-L v \overline{V \cdot \nabla q}\rangle$, Fig. 6c) derived from the PI and mid-Pliocene experiments both contribute less to the moist enthalpy advections $(-\langle\overline{V \cdot \nabla E}\rangle)$ and are thus neglected in the current study. The total dry enthalpy advections derived from the AGCM simulation for the PI and mid-Pliocene experiments shown in Fig. $6 \mathrm{~b}$ are largely attributed to the advection of the stationary eddy dry enthalpy by zonal-mean flow $\left(-\left\langle[C p \bar{V}] \cdot \overline{\nabla T^{*}}\right\rangle\right.$, Fig. 6e) and the advection of zonal-mean dry enthalpy by the stationary eddy velocity $\left(-\left\langle\overline{V^{*}} \cdot[C p \overline{\nabla T}]\right\rangle\right.$, Fig. 6h).

Following the same analysis method, we also examine the moist enthalpy advection $(-\langle\overline{V \cdot \nabla E}\rangle)$ and its associated components, the total dry enthalpy advection $(-\langle C p \overline{V \cdot \nabla T}\rangle)$, and the total latent heating advection $(-\langle-L v \overline{V \cdot \nabla q}\rangle)$ derived from the coupled simulations for the PI and mid-Pliocene experiments. The moist enthalpy advections $(-\langle\overline{V \cdot \nabla E}\rangle$, Fig. 7a) in the coupled simulations for the PI and mid-Pliocene experiments are also both largely determined by the total dry enthalpy advection $(-\langle-C p \overline{V \cdot \nabla T}\rangle$, Fig. $7 \mathrm{~b})$. The advection of the stationary eddy dry enthalpy by zonal-mean flow $\left(-\left\langle[C p \bar{V}] \cdot \overline{\nabla T^{*}}\right\rangle\right.$, Fig. 7e) and the advection of the zonal-mean dry enthalpy by the stationary eddy velocity $\left(-\left\langle\overline{V^{*}} \cdot[C p \overline{\nabla T}]\right\rangle\right.$, Fig. $\left.7 \mathrm{~h}\right)$ are both dominant factors determining the spatial patterns of the total dry enthalpy advection $(-\langle-C p \overline{V \cdot \nabla T}\rangle$, Fig. $7 b$ ) derived from the coupled simulations for the PI and mid-Pliocene experiments.

As discussed above, the total dry enthalpy advection $(-\langle-C p \overline{V \cdot \nabla T}\rangle)$ associated with its components $\left(-\left\langle[C p \bar{V}] \cdot \overline{\nabla T^{*}}\right\rangle\right.$ and $\left.-\left\langle\overline{V^{*}} \cdot[C p \overline{\nabla T}]\right\rangle\right)$ in both simulations are the dominant factors determining the spatial patterns of the JJA-averaged moist enthalpy advection $(-\langle\overline{V \cdot \nabla E}\rangle)$ over East Asia. Whether these aforementioned dominant factors used to identify the JJA-averaged moist enthalpy advection $(-\langle\overline{V \cdot \nabla E}\rangle)$ enable us to explain the moist enthalpy advection $(-\langle\overline{V \cdot \nabla E}\rangle)$ changes in the mid-Pliocene in the EASM domain derived from the AGCM and CGCM simulations is further discussed in the following paragraph. 


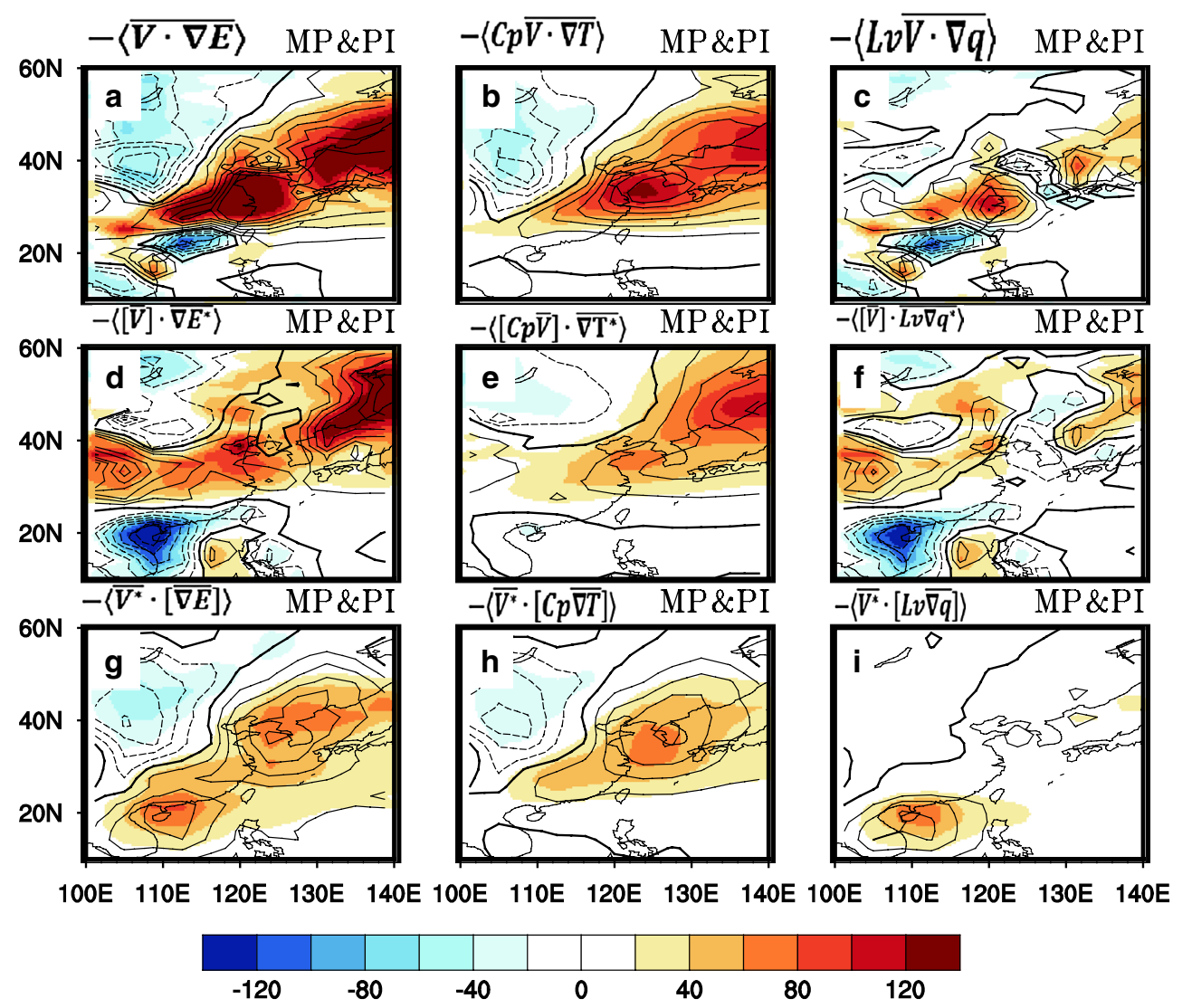

Fig. 6 a The AGCM-simulated JJA-averaged moist enthalpy advection $\left(-\langle\overline{V \cdot \nabla E}\rangle\right.$, units: $\left.\mathrm{W} \mathrm{m}^{-2}\right)$ derived from the PI and mid-Pliocene experiments, associated with separate contribution from the d stationary eddy energy by the zonal-mean flow $\left(-\left\langle[\bar{V}] \cdot \overline{\nabla E^{*}}\right\rangle\right)$ and $\mathbf{g}$ advection of the zonal-mean energy by the stationary eddy velocity
$\left(-\left\langle\overline{V^{*}} \cdot \overline{[\nabla E]}\right\rangle\right)$. Each of the terms shown in $\mathbf{a}, \mathbf{d}, \mathbf{g}$ is further divided into two terms: the corresponding temperature-relevant advection (b, $\mathbf{e}, \mathbf{h}$, middle column), and specific humidity-relevant advection (c, $\mathbf{f}$, i, right column). The simulated results from the PI and mid-Pliocene experiments are represented by contours and shading, respectively

dry enthalpy advection $(-\langle-C p \overline{V \cdot \nabla T}\rangle)$ increases on the northwestern flank of the aforementioned negative anomalies as a result of the combined contribution of the increased advection of the stationary eddy dry enthalpy by zonal-mean flow $\left(-\left\langle[C p \bar{V}] \cdot \overline{\left.\nabla T^{*}\right\rangle}\right)\right.$ extending from Northeast China to the Korean peninsula (Fig. 8e), and the advection of the zonal-mean dry enthalpy by the stationary eddy velocity $\left(-\left\langle\overline{V^{*}} \cdot[C p \overline{\nabla T}]\right\rangle\right)$ from Southwest China to the Shandong peninsula (Fig. 8h).

The CGCM-simulated moist enthalpy advection $(-\langle\bar{V} \cdot \nabla E\rangle)$ changes associated with the two components $-\left\langle[C p \bar{V}] \cdot \overline{\nabla T^{*}}\right\rangle$ and $-\left\langle\overline{V^{*}} \cdot[C p \overline{\nabla T}]\right\rangle$ the mid-Pliocene are also examined to identify the dominant factors determining the spatial pattern of moist enthalpy advection $(-\langle\overline{V \cdot \nabla E}\rangle)$ changes in the mid-Pliocene over East Asia (Fig. 9a, d, g). The enhanced moist enthalpy advection $(-\langle\overline{V \cdot \nabla E}\rangle$, Fig. 9a) in the CGCM mid-Pliocene simulation is also largely dominated by the general increase in the total dry enthalpy advection $(-\langle-C p \overline{V \cdot \nabla T}\rangle$, Fig. 9b), which is also attributed to the combined increases of advection of the stationary eddy dry enthalpy by zonal-mean flow 


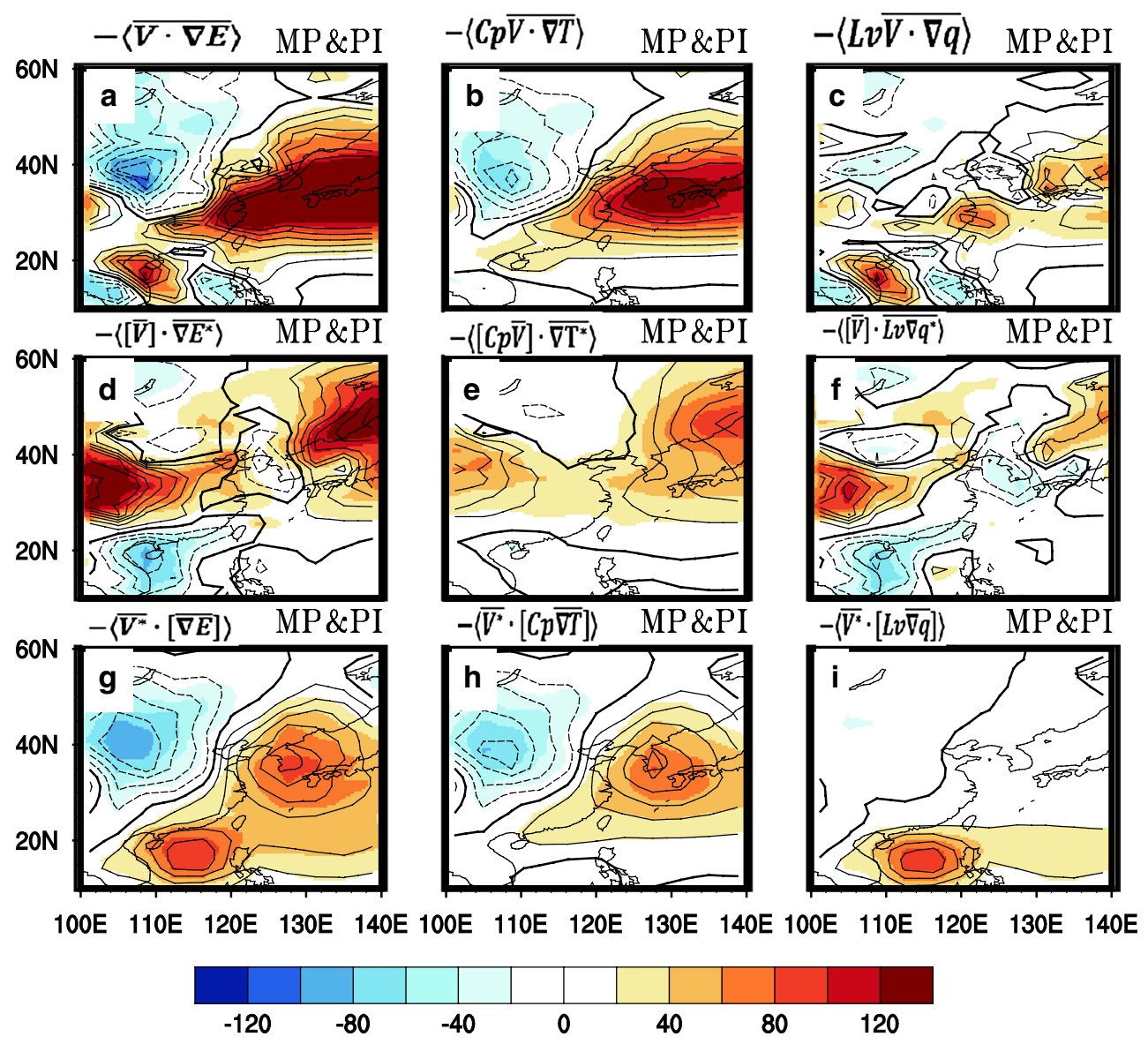

Fig. 7 As in Fig. 6 except for the simulated results derived from the CGCM (unit: $\mathrm{W} \mathrm{m}^{-2}$ )

$\left(-\left\langle[C p \bar{V}] \cdot \overline{\nabla T^{*}}\right\rangle\right)$ over East Asia and advection of the zonal mean dry enthalpy by the stationary eddy velocity $\left(-\left\langle\overline{V^{*}} \cdot[C p \overline{\nabla T}]\right\rangle\right)$ over China (Fig. 9e-h).

As discussed above, the moist enthalpy advection largely attributed to the dry enthalpy advection is a good gauge to describe the EASM precipitation with respect to its mean state and changes in the mid-Pliocene. As such, the JJA-averaged dry enthalpy advections in both simulations have been examined first to confirm the two dominant components of the dry enthalpy advection (advection of the stationary eddy dry enthalpy by zonal-mean flow $-\left\langle[C p \bar{V}] \cdot \overline{\nabla T^{*}}\right\rangle$ and advection of the zonal-mean dry enthalpy by the stationary eddy velocity $-\left\langle\overline{V^{*}} \cdot[C p \overline{\nabla T}]\right\rangle$ ) sustaining the spatial pattern of JJA-averaged dry moisture advection. These two components are also considered to be the two dominant factors determining the horizontal distribution of dry enthalpy advection changes in the midPliocene. This means that the two factors of (1) advection of the stationary eddy dry enthalpy by zonal-mean flow $\left(-\left\langle[C p \bar{V}] \cdot \overline{\nabla T^{*}}\right\rangle\right)$ and (2) advection of the zonal-mean dry enthalpy by the stationary eddy velocity $\left(-\left\langle\overline{V^{*}} \cdot[C p \overline{\nabla T}]\right\rangle\right)$ determining the dry enthalpy advection have also been identified as the dominant factors determining the spatial pattern of the EASM precipitation, as well as the enhanced mid-Pliocene EASM precipitation in both simulations.

Note that the advection of the stationary eddy dry

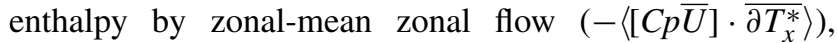
as the principal component of advection of the stationary eddy dry enthalpy by zonal-mean flow $\left(-\left\langle[C p \bar{V}] \cdot \overline{\nabla T^{*}}\right\rangle\right)$, largely determines the spatial distributions of advection of the stationary eddy dry enthalpy by zonal-mean flow $\left(-\left\langle[C p \bar{V}] \cdot \overline{\nabla T^{*}}\right\rangle\right)$ in both simulations in terms of the mean state and its changes in the mid-Pliocene (not shown). The advection of the zonal-mean dry enthalpy by the meridional stationary eddy velocity $\left(-\left\langle-C p \overline{V^{*}} \cdot\left[\overline{\partial T_{y}}\right]\right\rangle\right)$ is also a dominant component of the advection of the zonal-mean dry enthalpy by the stationary eddy velocity $\left(-\left\langle\overline{V^{*}} \cdot[C p \overline{\nabla T}]\right\rangle\right)$, thereby largely determining the spatial distributions of the advection of the zonal-mean dry enthalpy by the stationary eddy velocity $\left(-\left\langle\overline{V^{*}} \cdot[C p \overline{\nabla T}]\right\rangle\right)$ derived from the AGCM and CGCM simulations with respect to the mean state and associated changes in the 


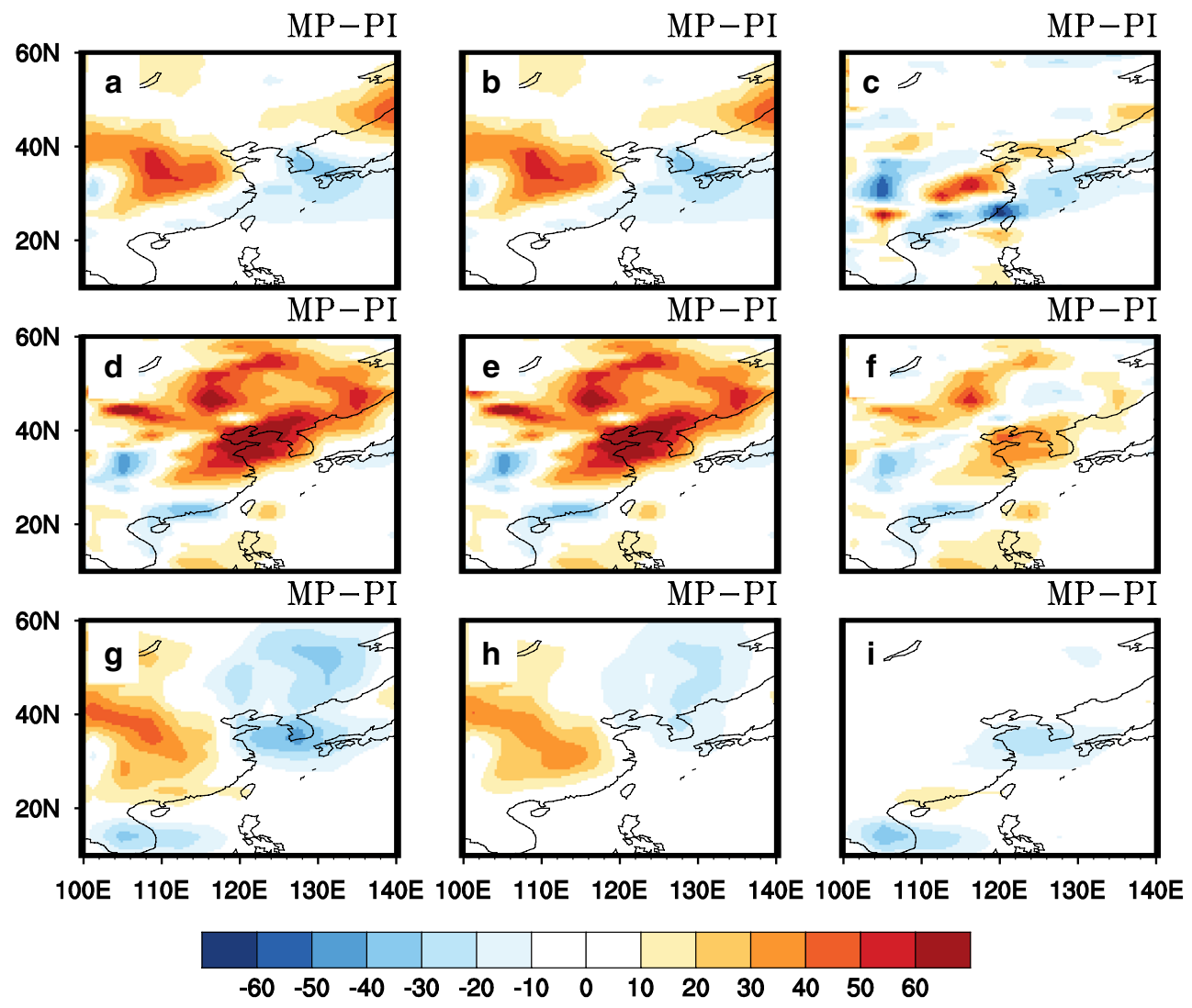

Fig. 8 The AGCM-simulated differences of the corresponding variables shown in Fig. 6 between the mid-Pliocene and PI experiments (units: $\mathrm{W} \mathrm{m}^{-2}$ )

mid-Pliocene (not shown). Here, we have focused on the effect of the advection of the stationary eddy dry enthalpy by zonal-mean zonal flow $\left(-\left\langle[C p \bar{U}] \cdot \overline{\partial T_{x}^{*}}\right\rangle\right)$ and advection of the zonal-mean dry enthalpy by the meridional stationary eddy velocity $\left(-\left\langle-C p \overline{V^{*}} \cdot\left[\overline{\partial T_{y}}\right]\right\rangle\right)$ on the enhanced mid-Pliocene EASM precipitation derived from the AGCM and CGCM simulations.

A recent modeling study confirmed that the spatial pattern of JJA-averaged advection of the stationary eddy dry enthalpy by zonal-mean zonal flow $\left(-\left\langle[C p \bar{U}] \cdot \overline{\partial T_{x}^{*}}\right\rangle\right)$ over East Asia indeed reflects the thermal effect of the Tibetan Plateau on the EASM circulation through enhancing the land-sea thermal contrast and transporting warm and moist air advection to downstream of the Tibetan Plateau into East Asia (Chen and Bodorni 2014a). In the current study, we use this term's $\left(-\left\langle[C p \bar{U}] \cdot \overline{\left.\left.\partial T_{x}^{*}\right\rangle\right)}\right.\right.$ changes in the midPliocene compared to the PI experiment to explain the enhanced mid-Pliocene EASM circulation and associated enhanced moisture transport from the tropical ocean to the EASM region (Fig. 10e, f). As shown in Fig. 2, the simulated zonal thermal contrasts are enhanced over East Asia in the mid-Pliocene derived from the AGCM and CGCM compared to the corresponding PI experiments, thereby strengthening the EASM circulation and moisture transport into the EASM region in both simulations (Fig. 10e, f), resulting in the enhanced mid-Pliocene EASM precipitation in both simulations (Fig. 3b).

Column-integrated meridional stationary eddy velocity $\left(\left\langle\overline{v^{*}}\right\rangle\right)$ as a component of the advection of the zonal-mean dry enthalpy by the meridional stationary eddy velocity $\left(\left(-\left\langle-C p \overline{V^{*}} \cdot\left[\overline{\partial T_{y}}\right]\right\rangle\right)\right.$ plays the fundamental role in determining the spatial pattern of the advection of the zonalmean dry enthalpy by the meridional stationary eddy velocity $\left(-\left\langle-C p \overline{V^{*}} \cdot\left[\overline{\partial T_{y}}\right]\right\rangle\right)$ with respect to its mean state and changes in the mid-Pliocene (not shown). Nevertheless, the way that the column-integrated meridional stationary eddy velocity $\left(\left\langle\overline{v^{*}}\right\rangle\right)$ effects the summer monsoon precipitation over East Asia remains to be further clarified. Zonally averaged meridional stationary eddy velocity $\left(\overline{v^{*}}\right)$ over East Asia can capture well the characteristics of the JJA-averaged EASM circulation derived from the AGCM and CGCM simulations, as evidenced by the prevailing southerlies (northerlies) in the lower (upper) troposphere associated with the lower-level (upper-level) convergence (divergence) induced by the non-uniform distribution of meridional stationary eddy velocity $\left(\overline{v^{*}}\right)$ over the EASM 


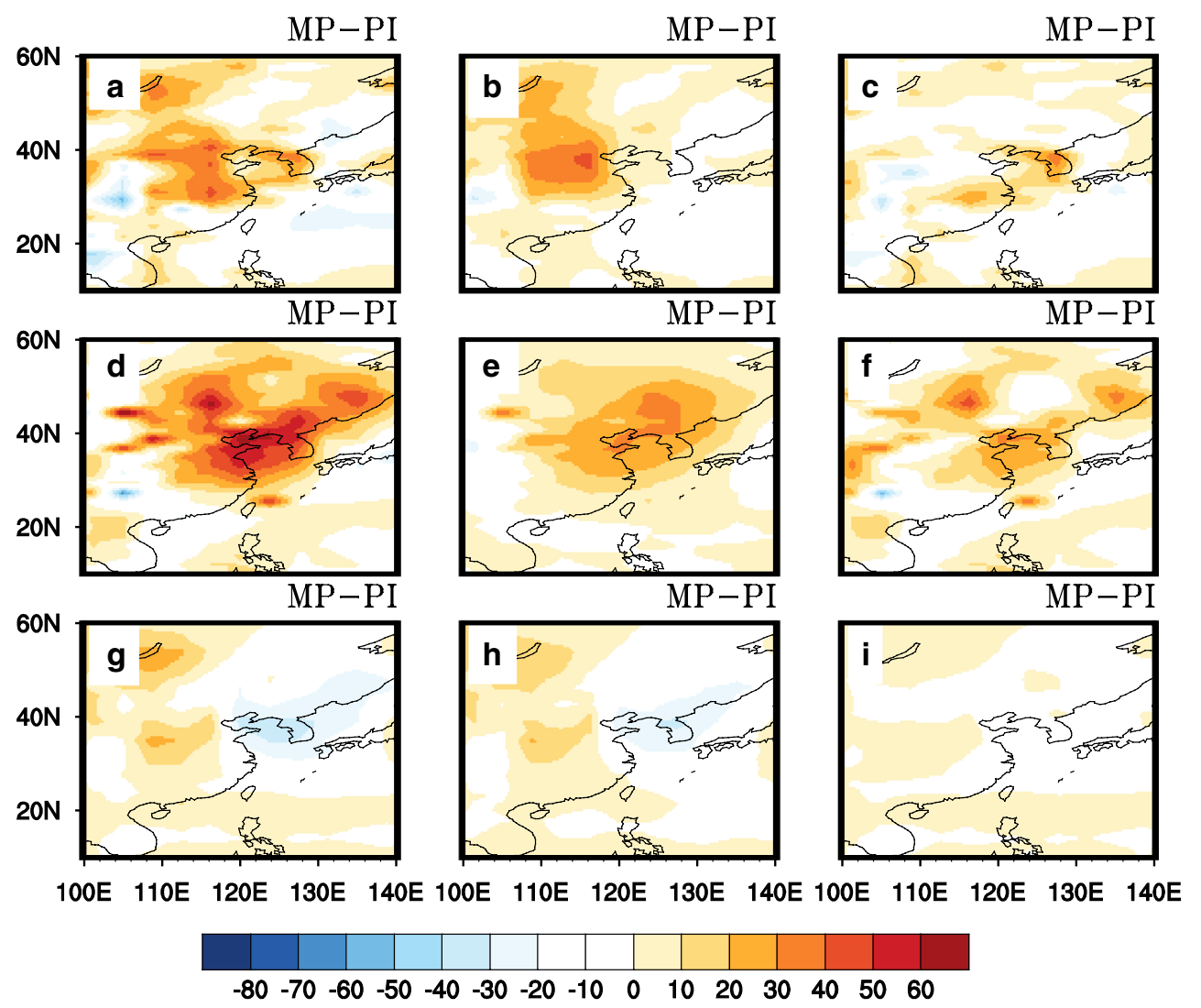

Fig. 9 The CGCM-simulated differences of the corresponding variables shown in Fig. 7 between the mid-Pliocene and PI experiments (units: $\mathrm{W} \mathrm{m}^{-2}$ )

domain (Fig. 11a, b, d, e). The simulated increase of meridional stationary eddy velocity $\left(\overline{v^{*}}\right)$ and its convergence $\frac{\overline{\partial v^{*}}}{\partial y}$ over the EASM domain are evident in the mid-Pliocene compared to the PI experiments in both simulations. These simulated increases are beneficial to the enhanced moisture transport into the EASM domain and increased local moisture convergence in the mid-Pliocene in both simulations, respectively (Fig. 11c, f). Therefore, these simulated increases of meridional stationary eddy velocity $\left(\overline{v^{*}}\right)$ and its convergence $\frac{\overline{\partial v^{*}}}{\partial y}$ over the EASM domain during the midPliocene in both simulations contribute to the enhanced EASM precipitation in the mid-Pliocene simulated by both the AGCM and the CGCM experiments (Fig. 3a, b).

\section{Explaining the differences in the mid-Pliocene EASM precipitation between CGCM and AGCM simulations}

Having identified the possible factors-advection of the stationary eddy dry enthalpy by zonal-mean zonal flow $\left(-\left\langle[C p \bar{U}] \cdot \overline{\partial T_{x}^{*}}\right\rangle\right)$ and column-integrated meridional stationary eddy velocity $\left(\left\langle\overline{v^{*}}\right\rangle\right)$ - determining the spatial patterns of JJA-averaged EASM precipitation and its changes in the mid-Pliocene relative to the corresponding PI experiments derived from the AGCM and CGCM simulations (Fig. 1a, b), we now turn our attention to the key issue of whether or not these factors can be used to explain the differences in EASM precipitation between the CGCM and AGCM simulations (Fig. 1c). The differences in the midPliocene moist enthalpy advection between the CGCM and AGCM simulations in terms of spatial distribution resemble the non-uniform distribution of the EASM precipitation differences between the CGCM and AGCM simulations (Figs. 1c, 12a). Therefore, moist enthalpy advection can also be considered as the dominant factor determining the simulated mid-Pliocene EASM precipitation differences between the CGCM and AGCM. Identifying the simulated differences of the dominant factors determining the moist enthalpy advection thus provides an alternative way to understand the mechanism controlling the simulated EASM precipitation difference between the two simulations.

The enhanced meridional thermal contrast derived from CGCM compared with the AGCM (Fig. 2c) leads to a weakened EASM circulation in the CGCM simulation compared to the AGCM simulation, associated with 
Fig. 10 Distributions of JJA mean potential height (contours, units: $\mathrm{m}$ ), moisture flux (vectors) at $850 \mathrm{hPa}$ and its magnitude (shading, $\mathrm{g} \mathrm{kg}^{-1}$ $\mathrm{m} \mathrm{s}^{-1}$ ) derived from the PI experiment simulated by the a AGCM and b CGCM. Panels $\mathbf{c}$, $\mathbf{d}$ are the same as $\mathbf{a}, \mathbf{b}$ except for the results for the mid-Pliocene. Panels $\mathbf{e}, \mathbf{f}$ are the same as $\mathbf{a}, \mathbf{b}$ except for the simulated differences between the mid-Pliocene and PI experiments
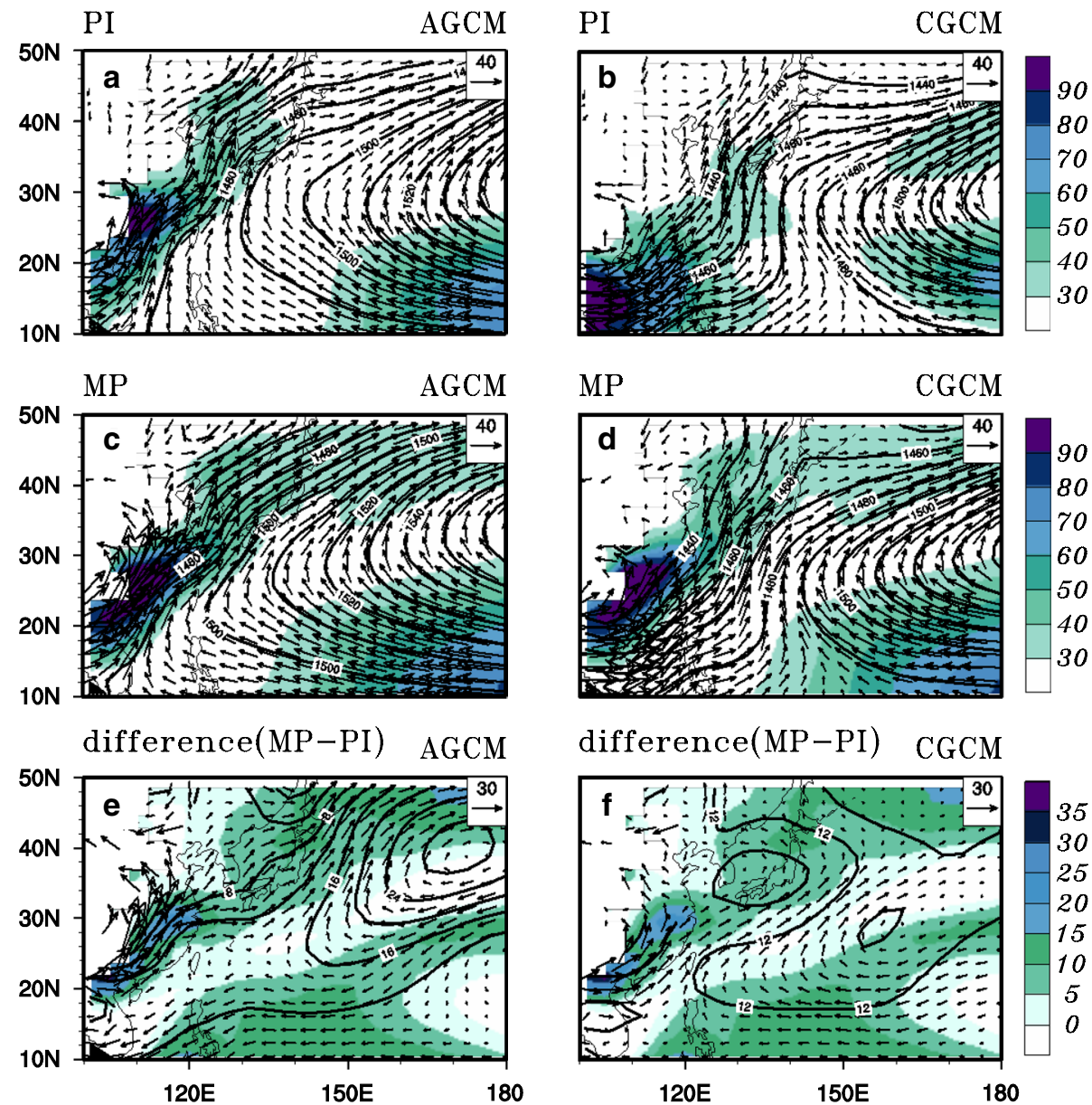

decreased moisture transport into East Asia (Fig. 12b), which results in decreased EASM precipitation over the northwest of South China (Fig. 1c). These results provide a reasonable explanation as to why the thermodynamic component of vertical moisture advection contributes negatively to the enhanced mean EASM precipitation in the mid-Pliocene CGCM simulation compared to the AGCM simulation (Fig. 3c). The weakened EASM in the mid-Pliocene CGCM simulation compared to the AGCM simulation is closely associated with the northeasterly anomalies on the northwestern flank of the anomalous cyclonic circulation dominant over South China and the South China Sea (Fig. 12b). This anomalous cyclone is closely linked to the warmer SST anomalies in the CGCM simulation than the AGCM simulation (Fig. 2d). Note that the weakened mid-Pliocene EASM circulation derived from CGCM simulation compared with the AGCM simulation features non-uniform spatial distributions, as evidenced by the simulated differences of meridional stationary eddy velocity convergence between the two simulations (Fig. 12c). This non-uniform weakening of the mid-Pliocene EASM circulation in the CGCM simulation compared to the AGCM simulation is highly consistent with the non-uniform distribution of the mid-Pliocene EASM precipitation differences between the CGCM and AGCM simulations (Fig. 1c). Relative to the AGCM, the CGCM-simulated increase of stationary eddy convergence over South China associated with increased vertical motion (Fig. 12f) thereby leads to the enhanced mid-Pliocene EASM precipitation over South China (Fig. 1c).

In brief, the enhanced meridional thermal contrast over the EASM domain and the increased stationary eddy convergence over South China both contribute to sustain the non-uniform distribution of the mid-Pliocene EASM precipitation difference between the CGCM and AGCM simulations. The former makes a positive contribution to the weakened precipitation in the CGCM simulation on the northwestern flank of South China, while the latter can explain well the enhanced precipitation over South China in the CGCM simulation relative to the AGCM simulation. Thus, the enhancement of area-averaged EASM precipitation in the CGCM relative to the AGCM is attributed to the increased dynamic component of vertical advection rather than the thermodynamic component (Fig. 3c). 

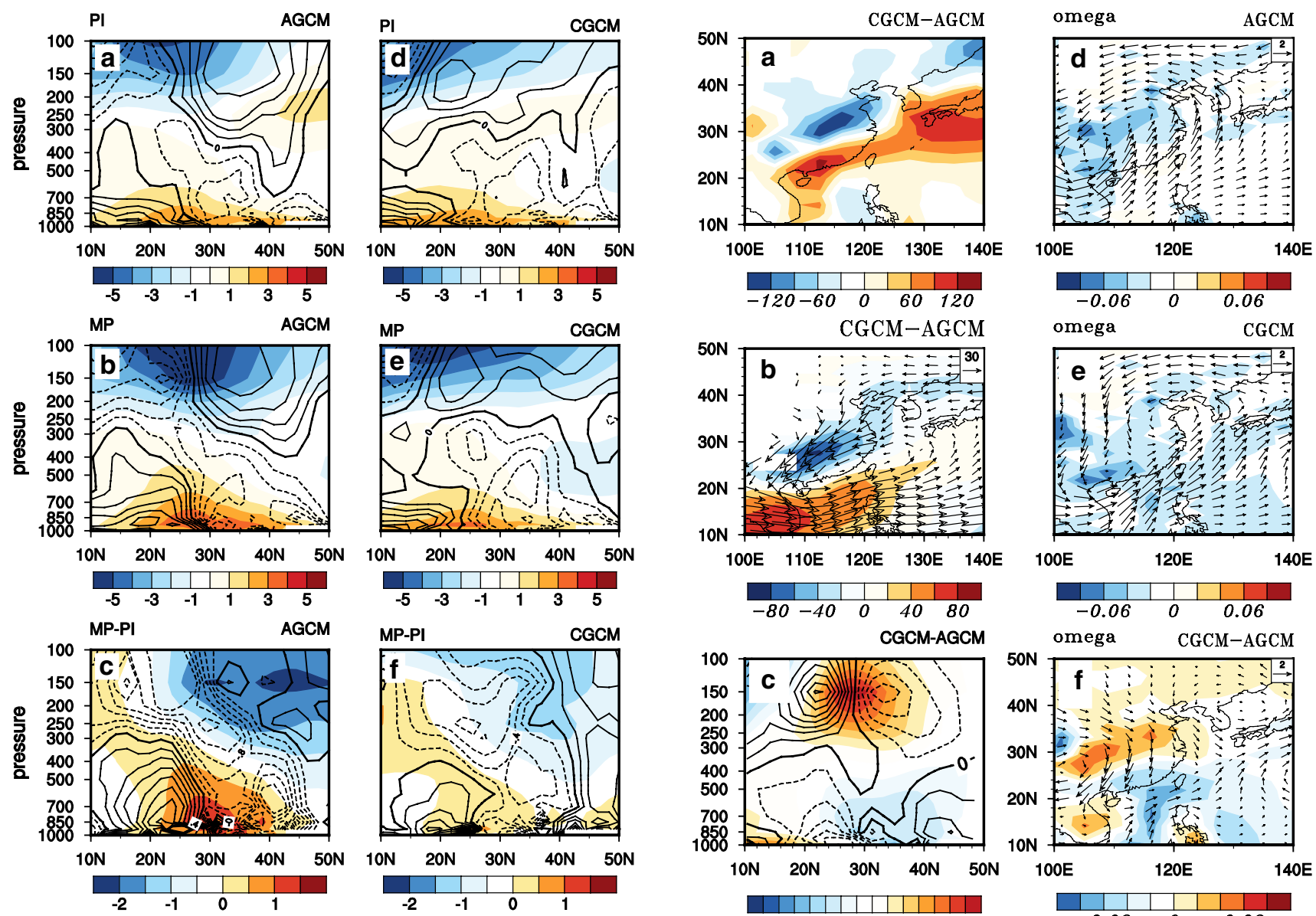

Fig. 11 The JJA-averaged meridional stationary eddy velocity $\left(\overline{v^{*}}\right.$, shading, units: $\left.\mathrm{m} \mathrm{s}^{-1}\right)$ over East Asia $\left(105^{\circ}-135^{\circ} \mathrm{E}\right)$ and its convergence $\left(\frac{\partial v^{*}}{\partial y}\right)$ (contours, units: $10^{-6} \mathrm{~s}^{-1}$, interval: $0.5 \times 10^{-6} \mathrm{~s}^{-1}$ ) derived from the AGCM (left column) and CGCM (right column) simulation for the PI and mid-Pliocene experiments. The simulated differences of the variables $\overline{v^{*}}$ (shading) and $\frac{\partial v^{*}}{\partial y}$ (contour interval: $0.2 \times 10^{-6} \mathrm{~s}^{-1}$ ) between the mid-Pliocene and PI experiments derived from c AGCM, f CGCM

\section{Multi-model comparisons}

Multi-model comparisons are also performed to validate the IPSL-CM5A -simulated drivers and mechanisms of the enhanced mid-Pliocene EASM circulation and increased precipitation in both simulations. We first examine the precipitation changes in response to mid-Pliocene surface warming in other PlioMIP1 models (Fig. 13a). There are a large inter-model spread in the response of mid-Pliocene EASM precipitation to surface warming over EASM domain, associated with no clear EASM precipitation change in FGOALS-g2 and a decreased EASM precipitation in another six models (MIROC4m-AGCM, MIROC4m-CGCM, CAM4, NorESM-L, ECHAM5 and CAM3.1). Nevertheless, the enhancement of mid-Pliocene EASM precipitation in IPSL-CM5A and its atmospheric
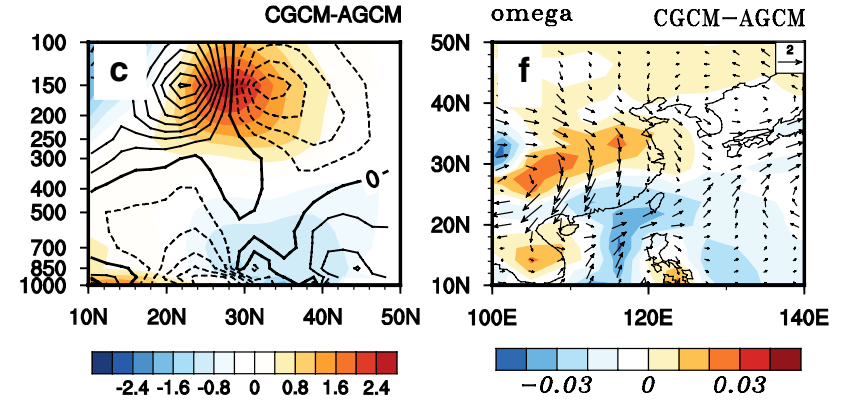

Fig. 12 The simulated differences between the CGCM and AGCM simulations for the following variables in the mid-Pliocene: $\mathbf{a}-\langle\overline{V \cdot \nabla E}\rangle$ (units: $\mathrm{W} \mathrm{m}^{-2}$ ); b moisture flux (vectors) at $850 \mathrm{hPa}$ and its magnitude (shading); $\mathbf{c} \overline{v^{*}}$ (shading, units: $\mathrm{m} \mathrm{s}^{-1}$ ) associated with $\frac{\overline{\partial \nu^{*}}}{\partial y}$ (contour interval: $0.5 \times 10^{-6} \mathrm{~s}^{-1}$ ) differences between the CGCM and AGCM simulations. JJA-averaged vertically averaged mid-Pliocene vertical velocity from 100 to $1000 \mathrm{hPa}$ (shading, units: $\mathrm{Pa} \mathrm{s}^{-1}$ ) and vertically integrated (normalized) stationary eddy wind fields (vectors, units: $\mathrm{m} \mathrm{s}^{-1}$ ) from 100 to $1000 \mathrm{hPa}$ derived from the $\mathbf{d}$ AGCM and e CGCM. $\mathbf{f}$ The simulated differences of the variables shown in $\mathbf{d}, \mathbf{e}$

component (LMDZ5) are also evident in other eight models (FGOALS-g2, GISS-E2-R, HadCM3, HadAM3, MRICGCM2.3-CGCM, MRI-CGCM2.3-AGCM, CCSM4, COSMOS) (Fig. 13a). These models used to validate the robustness of enhanced mid-Pliocene EASM precipitation based on IPSL-CM5A have been well documented in previous study (Zhang et al. 2013).

The enhanced zonal thermal contrast has been identified as a key mechanism controlling the enhancement of mid-Pliocene EASM precipitation by performing a comparative analysis of mid-Pliocene warm climate between IPSL-CM5A-LR and its stand-alone AGCM (LMDZ5) simulations. This enhanced zonal thermal contrast associated with column-integrated $\overline{v^{*}}$ increase is also evident in 


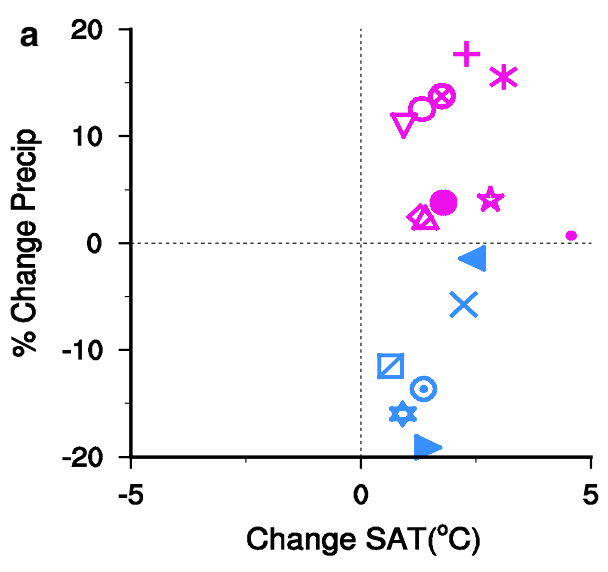

- FGOALS-g2 + GISS-E2-R * HadCM3 O HadAM3 X MIROC4m-CGCM $\square$ MIROC4m-AGCM $\triangle$ MRI-CGCM23-CGCM $\nabla$ MRI-CGCM23-AGCM $\diamond$ CCSM4 4 NorESM-L CAM4 * COSMOS \&ECHAM5 O CAM3.1 IPSL-CM5A LMDZ5

Zonal thermal contrast
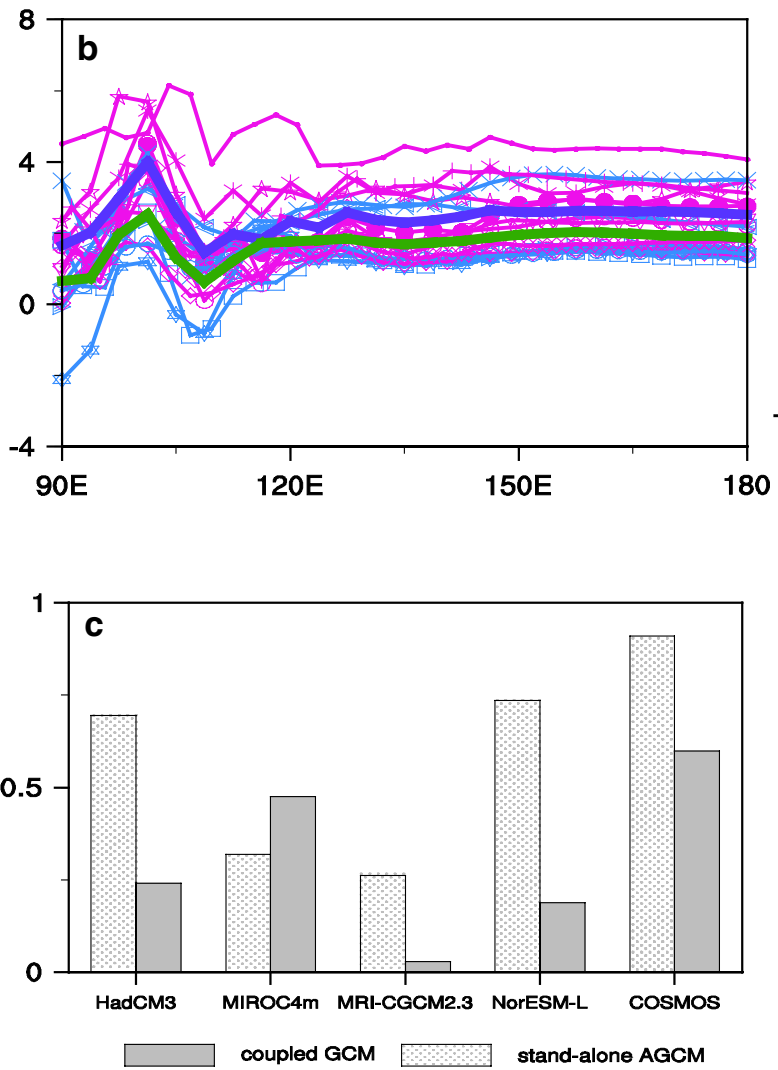

Fig. 13 The PlioMIP models simulated a mid-Pliocene EASM precipitation changes relative to PI experiment (by percentage)versus surface warming (units: ${ }^{\circ} \mathrm{C}$ ) over EASM domain; b zonal thermal contrast changes (units: ${ }^{\circ} \mathrm{C}$ ) in mid-Pliocene; c simulated columnintegrated $\overline{v^{*}}$ (units: $\mathrm{m} \mathrm{s}^{-1}$ ) changes in mid-Pliocene by PlioMIP models and the corresponding stand-alone AGCMs; d same as Fig. 3; except for the simulated differences of mid-Pliocene EASM precipi-
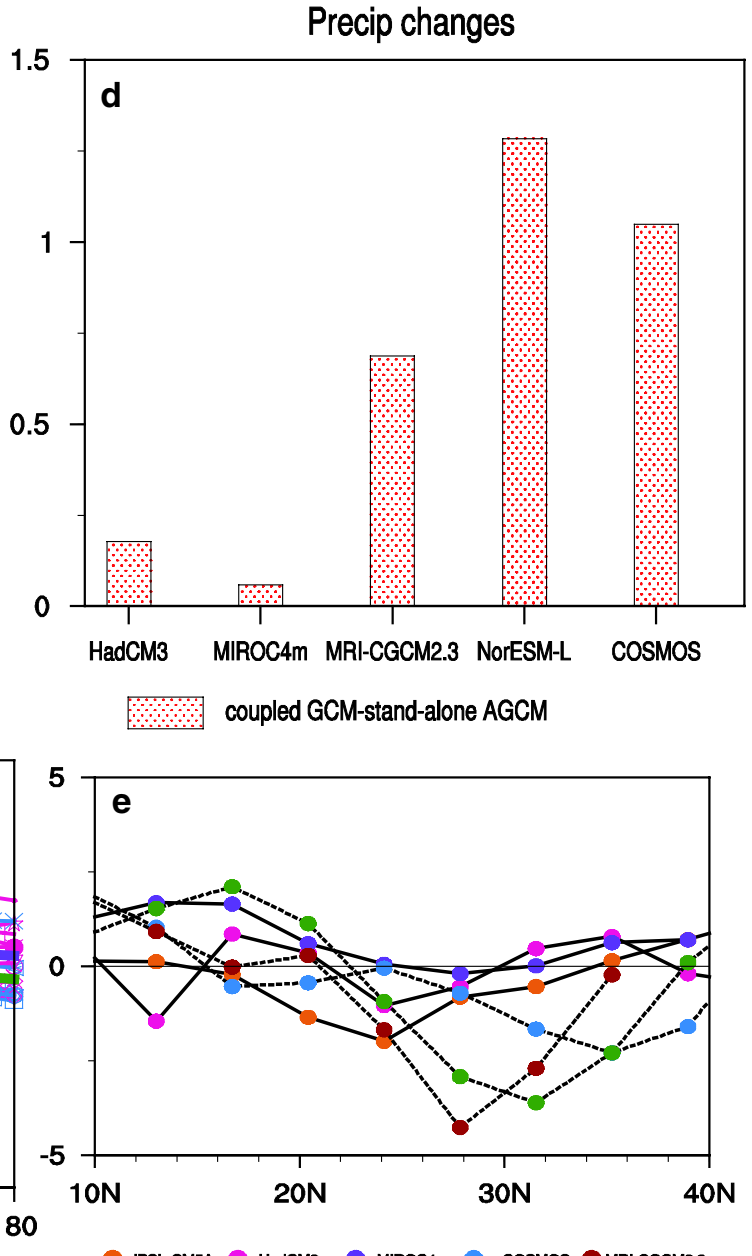

IPSL-CM5A HadCM3 MIROC4m cosMOS MRICGCM2.3

NorESM-L

SST bias

JJA

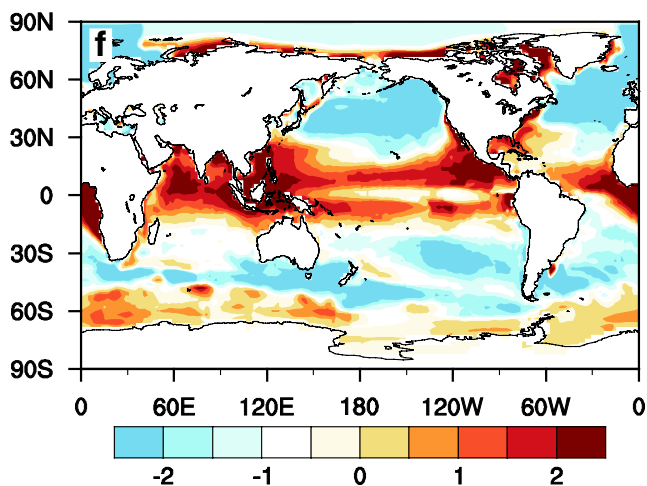

tation between CGCM and AGCM as represented by other PlioMIP models; e simulated differences of mid-Pliocene $\frac{\partial v^{*}}{\partial y}$ at $1000 \mathrm{hPa}$ (units: $\left.10^{-6} \mathrm{~s}^{-1}\right)$ averaged over $\left(105^{\circ}-135^{\circ} \mathrm{E}\right)$ between CGCM and AGCM derived from other PlioMIP models; f the SST bias (units: ${ }^{\circ} \mathrm{C}$ ) between multi-CGCMs ensemble mean and PRISM3 SST imposed in AGCMs 
(Fig. 13b, c), which are highly consistent with enhanced mid-Pliocene EASM precipitation revealed by these models. Note that a decrease of mid-Pliocene EASM precipitation revealed by other six models shown in Fig. 13a is also closely related to a weaker zonal thermal contrast in these models (Fig. 13b, thick purple: ensemble mean).

Multi-model comparisons are also carried out to investigate the simulated differences of mid-Pliocene EASM precipitation between CGCMs and corresponding atmospheric components. The simulated EASM precipitation is larger in these coupled models than their atmospheric components (Fig. 13d), which is consistent with the results from IPSLCM5A model. The multi-model simulated JJA-averaged convergence of meridional stationary eddy velocity $\left(\frac{\partial \nu^{*}}{\partial y}\right)$ at lower tropopause can well capture the lower-level convergence over the EASM domain (not shown), thus $\frac{\overline{\partial v^{*}}}{\partial y}$ has been considered a good metrics to gauge the mid-Pliocene EASM precipitation differences between the two simulations (Fig. 13e). The larger mid-Pliocene EASM precipitation in these CGCM simulations than their AGCM simulations is closely associated with CGCM-simulated increase in the $\frac{\partial v^{*}}{\partial y}$ over EASM domain compared to that of AGCM, despite that there are large inter-model spread of this convergence center over EASM domain (Fig. 13e). This increase of convergence of meridional stationary eddy velocity $\left(\frac{\overline{\partial v^{*}}}{\partial y}\right)$ over EASM domain in IPSL-CM5A simulation is driven by warmer SST anomalies over South China (Fig. 2d). There are also robust SST warmer biases over south China and tropical ocean between CGCM and PRISM3 SST imposed in stand-alone AGCM (Fig. 13f), which is consistent with the large overestimation of SST at low latitude in coupled PlioMIP1 models than PRISM3 SST in previous studies (Dowsett et al. 2013; Salzmann et al. 2013). Thus the larger simulated mid-Pliocene EASM precipitation in coupled models than their atmospheric components is essentially driven by this warmer SST biases between CGCM and AGCM over South China through inducing larger increase in $\frac{\overline{\partial v^{*}}}{\partial y}$ over EASM domain in coupled models than corresponding AGCMs. A data/model comparison on this area should be carried out in near future to investigate whether the SST in couple models or PRISM3 SST are realistic.

In brief, multi-model comparisons demonstrate that the relationships to explain the differences between CGCM and AGCM in the case of IPSL-CM5A have been confirmed when using the model database of PlioMIP. This result pinpoints the essential impact to have reliable SST reconstruction to infer the EASM evolution during mid-Pliocene.

\section{Summary and conclusions}

The drivers and mechanisms of enhanced summer monsoon precipitation over East Asia during the mid-Pliocene in atmosphere-only and coupled simulations with IPSLCM5A, as well as the simulated differences between the two simulations, are revealed in the present paper by performing a comparative analysis. This analysis demonstrates that the increase in area-averaged EASM summer precipitation in the mid-Pliocene simulations compared to the PI simulations is mostly driven by the increase in SAT over East Asia in both the mid-Pliocene simulations. The surface warming increases atmospheric moisture, thereby leading to an increased thermodynamic component of the vertical moisture advection. MSE diagnosis provides an effective way to identify the combined effect of enhanced thermal contrast and increased column-integrated meridional stationary eddy velocity $\left(\left\langle\overline{\left.v^{*}\right\rangle}\right)\right.$ as the principal mechanism controlling the large similarities and differences of the spatial patterns of EASM precipitation changes in the midPliocene between the two simulations. A simple schematic illustration is provided in Fig. 14 to summarize these drivers and mechanisms using moisture and MSE budget analysis, respectively. The study and its main conclusions can be summarized as follows:

By performing a moisture budget analysis in the EASM domain, we first examine the causes of the similarities and differences in area-averaged mid-Pliocene EASM precipitation changes compared to the PI experiments in both the simulations, as well as the differences in the mid-Pliocene EASM precipitation between the two simulations. The simulated mid-Pliocene precipitation over the EASM domain is enhanced in both simulations due to the increased vertical moisture advection in both simulations. The increased contribution of the thermodynamic component to the enhanced vertical moisture advection essentially reflects the response of atmospheric moisture to the mid-Pliocene global surface warming in both simulations. This result indicates that the enhanced mid-Pliocene EASM could be used as a test bed to further validate the projection of an intensified EASM in the future (Bao 2012). The dynamic component rather than thermodynamic component contributes to the increased vertical moisture advection in the CGCM simulation than the AGCM simulation, thereby leading to larger mid-Pliocene EASM precipitation in the CGCM simulation compared to the AGCM simulation.

The MSE budget analysis provides an effective way to identify the dominant factors determining the spatial distributions of JJA-averaged EASM precipitation and its changes in the mid-Pliocene derived from both simulations. The spatial patterns of the EASM precipitation with respect to the mean state and its changes in the mid-Pliocene derived from both simulations are explained well by the dry enthalpy advection. The advection of the stationary eddy dry enthalpy by zonal-mean zonal flow $\left(-\left\langle[C p \bar{U}] \cdot \overline{\left.\left.\partial T_{x}^{*}\right\rangle\right)}\right.\right.$ and the advection of the zonal-mean dry enthalpy by the meridional stationary eddy velocity $\left(-\left\langle-C p \overline{V^{*}} \cdot\left[\overline{\partial T_{y}}\right]\right\rangle\right)$ 
Fig. 14 Schematic diagram summarizing the drivers and mechanisms of the enhanced mid-Pliocene EASM precipitation compared to the PI experiment in both simulations, as well as the differences in the mid-Pliocene EASM precipitation between the two simulations, using moisture budget analysis and MSE budget analysis, respectively

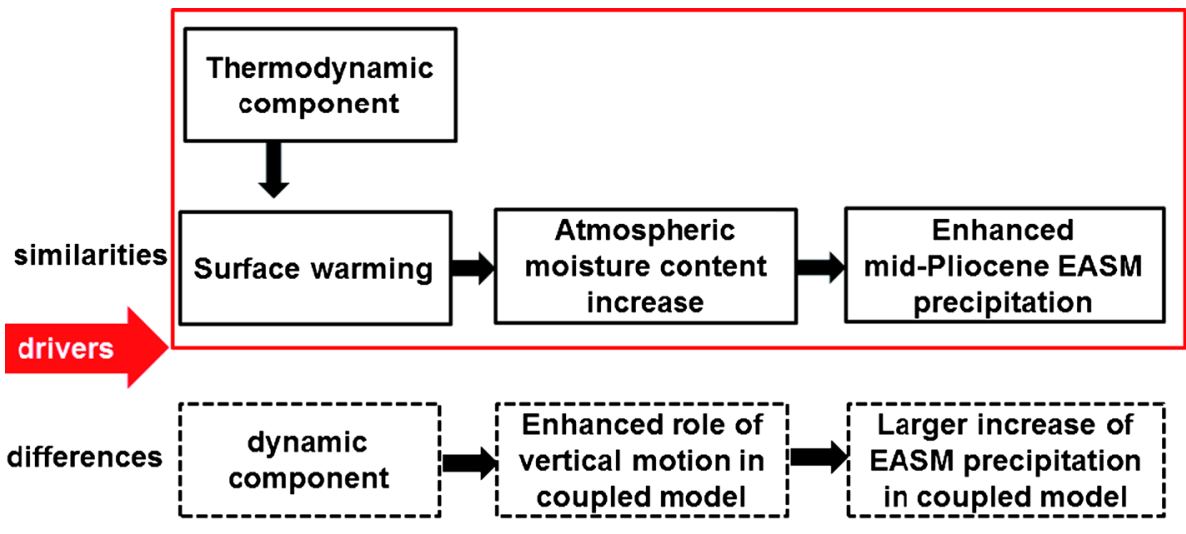

Moisture budget analysis on

area-averaged EASM precipitation changes

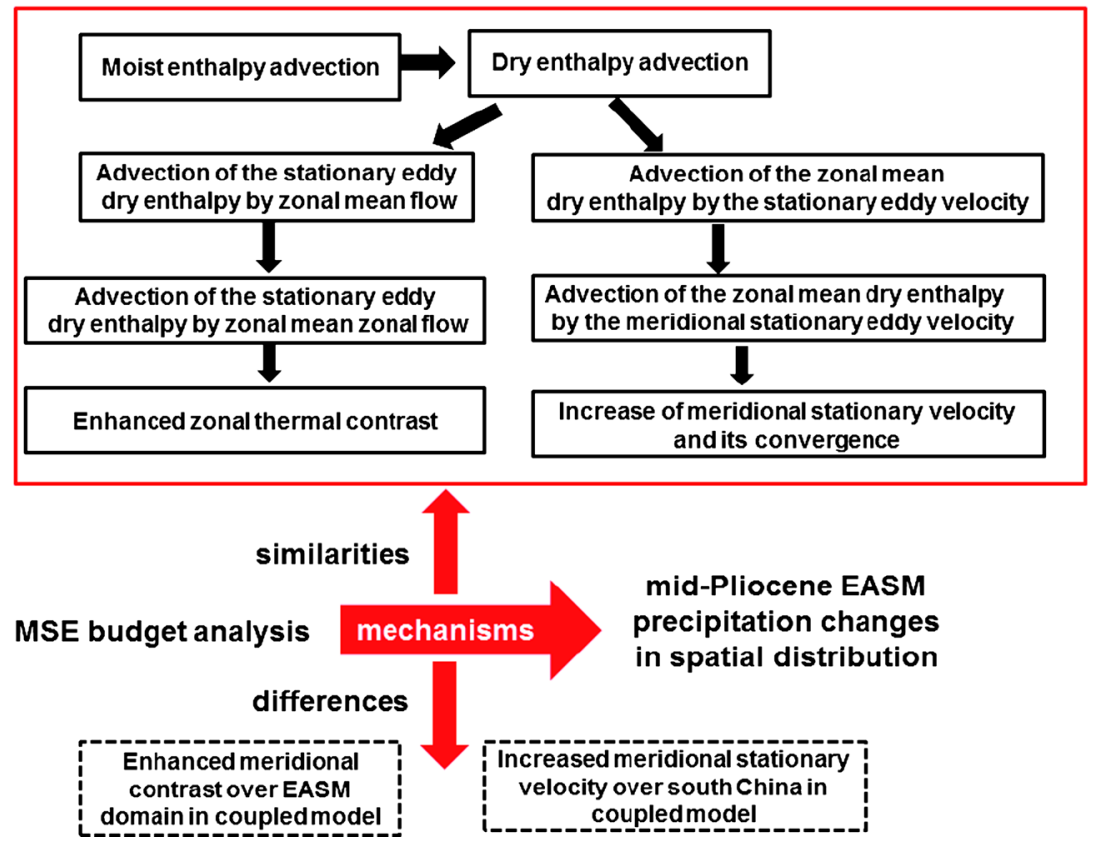

are identified as the two dominant components of the dry enthalpy advection, and thus they are selected to explain the EASM precipitation changes in the mid-Pliocene derived from both simulations. The simulated zonal thermal contrasts are enhanced over East Asia in the mid-Pliocene derived from both simulations, as evidenced by the advection of the stationary eddy dry enthalpy by zonal-mean zonal flow $\left(-\left\langle[C p \bar{U}] \cdot \overline{\partial T_{x}^{*}}\right\rangle\right)$, thereby strengthening the EASM circulation and moisture transport into the EASM domain, and thus contributing to the enhancement of the mid-Pliocene EASM precipitation derived from the AGCM and CGCM simulations compared with the corresponding PI experiments. Column-integrated meridional stationary eddy velocity $\left(\left\langle\overline{v^{*}}\right\rangle\right)$ as a dominant component of the advection of the zonal-mean dry enthalpy by the meridional stationary eddy velocity $\left(-\left\langle-C p \overline{V^{*}} \cdot\left[\overline{\partial T_{y}}\right]\right\rangle\right)$ can reasonably capture the characteristics of the JJA-averaged EASM circulation derived from the AGCM and CGCM simulations, and thus the enhanced column-integrated meridional stationary eddy velocity $\left(\left\langle\overline{v^{*}}\right\rangle\right)$ associated with the increase of lower-level convergence and upper-level divergence over the EASM domain also contribute to the enhancement of EASM precipitation in the mid-Pliocene derived from both simulations.

Simulated differences of the mid-Pliocene EASM precipitation between the CGCM and AGCM are non-uniform, despite the simulated EASM precipitation in the mid-Pliocene compared with the PI experiment being enhanced in both the 
AGCM and CGCM simulations. The enhanced meridional thermal contrast over the EASM domain and increased stationary eddy convergence over South China both contribute to sustain the non-uniform distribution of the mid-Pliocene EASM precipitation difference between the CGCM and AGCM simulations. The enhanced meridional thermal contrast contributes to the decreased EASM precipitation through weakening the EASM circulation and associated moisture transport. The weakening of EASM circulation is linked to the anomalous cyclone over South China induced by the warmer SST bias between the CGCM and the PRISM3 SST imposed in the AGCM. The increased stationary eddy convergence over South China provides a reasonable explanation for the enhanced precipitation associated with increased vertical motion over South China in the CGCM compared to that in the AGCM simulation. Therefore, the larger mean mid-Pliocene precipitation over the EASM domain in the CGCM simulation compared to the AGCM simulation is attributed to the enhanced vertical moisture advection; and it is the dynamic component rather than the thermodynamic component of the vertical moisture advection that contributes to the enhancement of vertical moisture advection.

Multi-model comparisons are carried out to validate the drivers and mechanisms of enhanced mid-Pliocene EASM precipitation, as revealed by IPSL-CM5A and its stand-alone LMZD5 simulations. The enhancement of midPliocene EASM precipitation relative to the corresponding PI experiments in two simulations driven by surface warming over EASM domain is also reproduced by another eight climate models (FGOALS-g2, GISS-E2-R, HadCM3, HadAM3, MRI-CGCM2.3-CGCM, MRI-CGCM2.3AGCM, CCSM4, COSMOS). The enhanced zonal thermal contrast simulated by these models has also considered to be a key mechanism controlling these enhanced midPliocene EASM precipitation in both simulations through strengthening the moisture transport into EASM domain and inducing an increase in the local convergence of meridional stationary eddy velocity.

The mid-Pliocene EASM precipitation produced by other coupled models (HadCM3, MIROC4 m-CGCM, MRI-CGCM2.3-CGCM, NorESM-L and COSMOS) is also larger than those in stand-alone AGCM (HadAM3, MIROC4 m-AGCM, MRI-CGCM2.3-AGCM, CAM4 and ECHAM5) simulations. Here we explain the lager simulated EASM precipitation in coupled models than their atmospheric components by examining the dominator factors in determining these differences and their connection to warmer SST anomalies. The $\frac{\partial v^{*}}{\partial y}$ has been considered a good metric to gauge the mid-Pliocene EASM precipitation differences between the two simulations. The larger simulated EASM precipitation is associated with an increase in the $\frac{\partial v^{*}}{\partial y}$ to south of $20^{\circ} \mathrm{N}$, despite there are large inter-model spread of the convergence center over the
EASM domain. The simulated $\frac{\overline{\partial v^{*}}}{\partial y}$ increase matches well with the warmer SST anomalies between multi-CGCM ensemble mean and PRISM3 SST imposed in stand-alone AGCM. In present study, we emphasize the primary role of the local warmer SST anomalies over Southern China in the simulated $\frac{\partial v^{*}}{\partial y}$ increase; despite that larger warm SST bias also exist in the tropical ocean. In addition, we should note the warmer SST in other oceans such as the Indian Ocean. In present climate, a warmer tropical Indian Ocean at both interannual and inter-decadal time scales would affect the EASM by forcing an Indian Ocean-Western Pacific anticyclone tele-connection pattern (Zhou et al. 2008; Wu et al. 2010; Song and Zhou 2014a, b), whether a similar mechanism works in mid-Pliocene warrants further study.

Acknowledgments This work is jointly supported by National Natural Science Foundation of China under Grant Nos. 41330423 and 41420104006.

Open Access This article is distributed under the terms of the Creative Commons Attribution 4.0 International License (http://creativecommons.org/licenses/by/4.0/), which permits unrestricted use, distribution, and reproduction in any medium, provided you give appropriate credit to the original author(s) and the source, provide a link to the Creative Commons license, and indicate if changes were made.

\section{References}

Bao Q (2012) Projected changes in Asian summer monsoon in RCP scenarios of CMIP5. Atmos Ocean Sci Lett 5(1):43-48

Bragg FJ, Lunt DJ, Haywood AM (2012) Mid-Pliocene climate modelled using the UK Hadley Centre Model: PlioMIP Experiments 1 and 2. Geosci Model Dev 5(5):1109-1125. doi:10.5194/ gmd-5-1109-2012

Chan WL, Abe-Ouchi A, Ohgaito R (2011) Simulating the mid-Pliocene climate with the MIROC general circulation model: experimental design and initial results. Geosci Model Dev 4(4):10351049. doi:10.5194/gmd-4-1035-2011

Chandler MA, Sohl LE, Jonas JA, Dowsett HJ, Kelley M (2013) Simulations of the mid-Pliocene warm period using two versions of the NASA/GISS ModelE2-R Coupled Model. Geosci Model Dev 6(2):517-531. doi:10.5194/gmd-6-517-2013

Chen J, Bordoni S (2014a) Orographic effects of the Tibetan Plateau on the East Asian summer monsoon: an energetic perspective. $\mathbf{J}$ Clim 27(8):3052-3072. doi:10.1175/jcli-d-13-00479.1

Chen J, Bordoni S (2014b) Intermodel spread of East Asian summer monsoon simulations in CMIP5. Geophys Res Lett 41(4):13141321. doi: $10.1002 / 2013 \mathrm{gl} 1058981$

Chou C, Lan C-W (2012) Changes in the annual range of precipitation under global warming. J Clim 25(1):222-235. doi:10.1175/ jcli-d-11-00097.1

Chou C, Chiang J C H, Lan C-W, Chung C-H, Liao Y-C, Lee C-J (2013) Increase in the range between wet and dry season precipitation. Nat Geosci 6(4):263-267. http://www.nature.com/ngeo/ journal/v6/n4/abs/ngeo1744.html\#supplementary-information

Contoux C, Ramstein G, Jost A (2012) Modelling the mid-Pliocene Warm Period climate with the IPSL coupled model and its 
atmospheric component LMDZ5A. Geosci Model Dev 5(3):903917. doi:10.5194/gmd-5-903-2012

Dowsett HJ, Foley KM, Stoll DK, Chandler MA, Sohl LE, Bentsen M, Otto-Bliesner BL, Bragg FJ, Chan W-L, Contoux C, Dolan AM, Haywood AM, Jonas JA, Jost A, Kamae Y, Lohmann G, Lunt DJ, Nisancioglu KH, Abe-Ouchi A, Ramstein G, Riesselman CR, Robinson MM, Rosenbloom NA, Salzmann U, Stepanek C, Strother SL, Ueda H, Yan Q, Zhang Z (2013) Sea surface temperature of the mid-Piacenzian Ocean: a data-model comparison. Sci Rep. doi:10.1038/srep02013

Dufresne JL, Foujols MA, Denvil S, Caubel A, Marti O, Aumont O, Balkanski Y, Bekki S, Bellenger H, Benshila R, Bony S, Bopp L, Braconnot P, Brockmann P, Cadule P, Cheruy F, Codron F, Cozic A, Cugnet D, de Noblet N, Duvel JP, Ethé C, Fairhead L, Fichefet T, Flavoni S, Friedlingstein P, Grandpeix JY, Guez L, Guilyardi E, Hauglustaine D, Hourdin F, Idelkadi A, Ghattas J, Joussaume S, Kageyama M, Krinner G, Labetoulle S, Lahellec A, Lefebvre MP, Lefevre F, Levy C, Li ZX, Lloyd J, Lott F, Madec G, Mancip M, Marchand M, Masson S, Meurdesoif Y, Mignot J, Musat I, Parouty S, Polcher J, Rio C, Schulz M, Swingedouw D, Szopa S, Talandier C, Terray P, Viovy N, Vuichard N (2013) Climate change projections using the IPSL-CM5 earth system model: from CMIP3 to CMIP5. Clim Dyn 40(910):2123-2165. doi:10.1007/s00382-012-1636-1

Edwards M (1992) Global gridded elevation and bathymetry. In: Kineman JJ, and Ohrenschall MA (eds) Global ecosystems database, version 1.0 (on CD-ROM), Documentation annual, disc-A: National Geophysical Data Center, Key to Geophysical Records Documentation No. 26 (Incorporated in: Global Change Database, Volume 1). National Oceanic and Atmospheric Administration, Boulder, CO, pp A14-1 to A14-4

Fichefet T, Morales-Maqueda AM (1997) Sensitivity of a global sea ice model to the treatment of ice thermodynamics and dynamics. J Geophys Res 102(C6):12609-12646. doi:10.1029/97jc00480

Haywood AM, Valdes PJ (2004) Modelling Pliocene warmth: contribution of atmosphere, oceans and cryosphere. Earth Planet Sci Lett 218(3-4):363-377. doi:10.1016/S0012-821X(03)00685-X

Haywood AM, Valdes PJ, Sellwood BW (2000) Global scale palaeoclimate reconstruction of the middle Pliocene climate using the UKMO GCM: initial results. Glob Planet Change 25(3-4):239 256. doi:10.1016/S0921-8181(00)00028-X

Haywood AM, Dowsett HJ, Otto-Bliesner B, Chandler MA, Dolan AM, Hill DJ, Lunt DJ, Robinson MM, Rosenbloom N, Salzmann U, Sohl LE (2010) Pliocene Model Intercomparison Project (PlioMIP): experimental design and boundary conditions (Experiment 1). Geosci Model Dev 3(1):227-242. doi:10.5194/ gmd-3-227-2010

Haywood AM, Dowsett HJ, Robinson MM, Stoll DK, Dolan AM, Lunt DJ, Otto-Bliesner B, Chandler MA (2011) Pliocene Model Intercomparison Project (PlioMIP): experimental design and boundary conditions (Experiment 2). Geosci Model Dev 4(3):571-577. doi:10.5194/gmd-4-571-2011

Haywood AM, Hill DJ, Dolan AM, Otto-Bliesner BL, Bragg F, Chan WL, Chandler MA, Contoux C, Dowsett HJ, Jost A, Kamae Y, Lohmann G, Lunt DJ, Abe-Ouchi A, Pickering SJ, Ramstein G, Rosenbloom NA, Salzmann U, Sohl L, Stepanek C, Ueda H, Yan Q, Zhang Z (2013) Large-scale features of Pliocene climate: results from the Pliocene Model Intercomparison Project. Clim Past 9(1):191-209. doi:10.5194/cp-9-191-2013

Hill DJ, Haywood AM, Hindmarsh RCA, Valdes PJ (2007) Characterising ice sheets during the mid-Pliocene: evidence from data and models. In: Williams M, Haywood AM, Gregory FJ, Schmidt DH (eds) Deep time perspectives on climate change: marrying the signal from computer models and biological proxies. Micropalaeontol. Soc., Spec. Pub. Geol. Soc., London, pp 517-538
Hill DJ, Haywood AM, Lunt DJ, Hunter SJ, Bragg FJ, Contoux C, Stepanek C, Sohl L, Rosenbloom NA, Chan WL, Kamae Y, Zhang Z, Abe-Ouchi A, Chandler MA, Jost A, Lohmann G, Otto-Bliesner BL, Ramstein G, Ueda H (2014) Evaluating the dominant components of warming in Pliocene climate simulations. Clim Past 10(1):79-90. doi:10.5194/cp-10-79-2014

Hourdin F, Foujols M-A, Codron F, Guemas V, Dufresne J-L, Bony S, Denvil S, Guez L, Lott F, Ghattas J, Braconnot P, Marti O, Meurdesoif Y, Bopp L (2013) Impact of the LMDZ atmospheric grid configuration on the climate and sensitivity of the IPSL-CM5A coupled model. Clim Dyn 40(9-10):2167-2192. doi:10.1007/s00382-012-1411-3

Hsu P, Li T, Luo J, Murakami H, Kitoh A (2012) Increase of global monsoon area and precipitation under global warming: a robust signal? Geophys Res Lett 39:L06701. doi:10.1029/201 2GL051037

Jansen E, Overpeck J, Briffa K R, Duplessy J-C, Joos F, Masson-Delmotte V, Olago D, Otto-Bliesner B, Peltier W R, Rahmstorf S, Ramesh R, Raynaud D, Rind D, Solom-ina O, Villalba R, Zhang D (2007) Palaeoclimate. In: Solomon S, Qin D, Manning M, Chen Z, Marquis M, Averyt KB, Tignor M, Miller HL Climate change 2007: the physical science basis. Contribution of working group I to the fourth assessment report of the intergovernmental panel on climate change. Cambridge University Press, Cambridge

Kamae Y, Ueda H (2012) Mid-Pliocene global climate simulation with MRI-CGCM2.3: set-up and initial results of PlioMIP Experiments 1 and 2. Geosci Model Dev 5(3):793-808. doi:10.5194/ gmd-5-793-2012

Koenig SJ, DeConto RM, Pollard D (2012) Pliocene Model Intercomparison Project Experiment 1: implementation strategy and midPliocene global climatology using GENESIS v3.0 GCM. Geosci Model Dev 5(1):73-85. doi:10.5194/gmd-5-73-2012

Krinner G, Viovy N, de Noblet-Ducoudré N, Ogée J, Polcher J, Friedlingstein P, Ciais P, Sitch S, Prentice I C (2005) A dynamic global vegetation model for studies of the coupled atmospherebiosphere system. Global Biogeochem Cycles 19(1):GB1015. doi: $10.1029 / 2003 \mathrm{gb} 002199$

Madec G (2008) NEMO ocean engine, note du Pole de modelisation, Institut Pierre-Simon Laplace (IPSL)

Miller KG, Wright JD, Browning JV, Kulpecz A, Kominz M, Naish TR, Cramer BS, Rosenthal Y, Peltier WR, Sosdian S (2012) High tide of the warm Pliocene: implications of global sea level for Antarctic deglaciation. Geology. doi:10.1130/g32869.1

Rosenbloom NA, Otto-Bliesner BL, Brady EC, Lawrence PJ (2013) Simulating the mid-Pliocene Warm Period with the CCSM4 model. Geosci Model Dev 6(2):549-561. doi:10.5194/ gmd-6-549-2013

Salzmann U, Haywood AM, Lunt DJ, Valdes PJ, Hill DJ (2008) A new global biome reconstruction and data-model comparison for the Middle Pliocene. Global Ecol Biogeogr 17(3):432-447. doi:10.1111/j.1466-8238.2008.00381.x

Salzmann U, Dolan AM, Haywood AM, Chan W-L, Voss J, Hill DJ, Abe-Ouchi A, Otto-Bliesner B, Bragg FJ, Chandler MA, Contoux C, Dowsett HJ, Jost A, Kamae Y, Lohmann G, Lunt DJ, Pickering SJ, Pound MJ, Ramstein G, Rosenbloom NA, Sohl L, Stepanek C, Ueda H, Zhang Z (2013) Challenges in quantifying Pliocene terrestrial warming revealed by data-model discord. Nat Clim Change 3(11):969-974. doi:10.1038/nclimate2008

Sampe T, Xie S-P (2010) Large-scale dynamics of the Meiyu-Baiu rainband: environmental forcing by the westerly jet*. J Clim 23(1):113-134. doi:10.1175/2009jcli3128.1

Seo K, Ok J, Son J, Cha D (2013) Assessing future changes in the East asian summer monsoon using CMIP5 coupled models. J Clim 26:7662-7675 
Sohl LE, Chandler MA, Schmunk RB, Mankoff K, Jonas JA, Foley KM, Dowsett HJ (2009) PRISM3/GISS topographic reconstruction, US Geol. Surv. Data Series, vol 419, 6 pp

Song F, Zhou T (2014a) Interannual variability of East Asian summer monsoon simulated by CMIP3 and CMIP5 AGCMs: skill dependence on Indian Ocean-Western Pacific anticyclone teleconnection. J Clim 27(4):1679-1697. doi:10.1175/jcli-d-13-00248.1

Song F, Zhou T (2014b) The climatology and interannual variability of East Asian summer monsoon in CMIP5 coupled models: does air-sea coupling improve the simulations? J Clim 27(23):87618777. doi:10.1175/jcli-d-14-00396.1

Stepanek C, Lohmann G (2012) Modelling mid-Pliocene climate with COSMOS. Geosci Model Dev 5(5):1221-1243. doi:10.5194/ gmd-5-1221-2012

Sun Y, Ramstein G, Contoux C, Zhou T (2013) A comparative study of large-scale atmospheric circulation in the context of a future scenario (RCP4.5) and past warmth (mid-Pliocene). Clim Past 9(4):1613-1627. doi:10.5194/cp-9-1613-2013

Thompson RS, Fleming RF (1996) Middle Pliocene vegetation: reconstructions, paleoclimatic inferences, and boundary conditions for climate modeling. Mar Micropaleontol 27(1-4):27-49. doi:10.1016/0377-8398(95)00051-8

Valcke S (2006) OASIS3 user guide (prism_2-5) technical report TR/ CMGC/06/73, CERFACS, Toulouse, France http://www.cerfacs. fr/3-25801-Technical-Reports.php

Wu B, Li T, Zhou T (2010) Relative contributions of the Indian Ocean and local SST anomalies to the maintenance of the Western North Pacific anomalous anticyclone during the El Niño decaying summer*. J Clim 23(11):2974-2986. doi:10.1175/2010jcli3300.1

Yan Q, Zhang ZS, Wang HJ, Gao YQ, Zheng WP (2012a) Set-up and preliminary results of mid-Pliocene climate simulations with CAM3.1. Geosci Model Dev 5(2):289-297. doi:10.5194/ gmd-5-289-2012

Yan Q, Zhang ZS, Gao YQ (2012b) An East Asian Monsoon in the Mid-Pliocene. Atmos Oceanic Sci Lett 5(6):449-454

Yoon J, Chen T (2005) Water vapor budget of the Indian monsoon depression. Tellus 57A:770-782. doi:10.1111/j.1600-0870.2005.00145.x

Zhang Z, Yan Q (2012) Pre-industrial and mid-Pliocene simulations with NorESM-L: AGCM simulations. Geosci Model Dev 5(4):1033-1043. doi:10.5194/gmd-5-1033-2012

Zhang ZS, Nisancioglu K, Bentsen M, Tjiputra J, Bethke I, Yan Q, Risebrobakken B, Andersson C, Jansen E (2012) Pre-industrial and mid-Pliocene simulations with NorESM-L. Geosci Model Dev 5(2):523-533. doi:10.5194/gmd-5-523-2012

Zhang R, Yan Q, Zhang ZS, Jiang D, Otto-Bliesner BL, Haywood AM, Hill DJ, Dolan AM, Stepanek C, Lohmann G, Contoux C, Bragg F, Chan WL, Chandler MA, Jost A, Kamae Y, Abe-Ouchi A, Ramstein G, Rosenbloom NA, Sohl L, Ueda H (2013) MidPliocene East Asian monsoon climate simulated in the PlioMIP. Clim Past 9(5):2085-2099. doi:10.5194/cp-9-2085-2013

Zhang R, Jiang D, Zhang ZS (2015) Causes of mid-Pliocene strengthened summer and weakened winter monsoons over East Asia. Adv Atmos Sci 32(7):1016-1026. doi:10.1007/ s00376-014-4183-3

Zheng W, Zhang Z, Chen L, Yu Y (2013) The mid-Pliocene climate simulated by FGOALS-g2. Geosci Model Dev 6(4):1127-1135. doi:10.5194/gmd-6-1127-2013

Zhou T, Yu R, Li H, Wang B (2008) Ocean forcing to changes in global monsoon precipitation over the recent half-century. J Clim 21(15):3833-3852. doi:10.1175/2008jcli2067.1 